\title{
Prospects for Agricultural Sustainable Intensification: A Review of Research
}

\author{
Hualin Xie ${ }^{1, *}$, Yingqian Huang ${ }^{1}$, Qianru Chen ${ }^{1}$, Yanwei Zhang ${ }^{2}$ and Qing $\mathrm{Wu}^{1}$ \\ 1 Institute of Ecological Civilization, Jiangxi University of Finance and Economics, Nanchang 330013, China; \\ hyq162545@163.com (Y.H.); cqrjufc@163.com (Q.C.); wuqing_carpediem@163.com (Q.W.) \\ 2 School of Tourism and Urban Management, Jiangxi University of Finance and Economics, \\ Nanchang 330032, China; bsonyan@126.com \\ * Correspondence: xiehl_2000@163.com; Tel.: +86-791-8397-9115
}

Received: 28 September 2019; Accepted: 22 October 2019; Published: 23 October 2019

check for updates

\begin{abstract}
In recent years, as a way to achieve higher agricultural output while reducing the negative impact of agricultural production on the environment, agricultural sustainable intensification has attracted worldwide attention. Under the framework of "connotation definition-measuring method-influencing factor-implementation path", this paper systematically sorts out the main research results in the field of agricultural sustainable intensification. The results show that: (1) The connotation of agricultural sustainable intensification has not been clearly defined. It is widely believed that sustainable intensification has the characteristics of increasing production and reducing environmental damage, and is widely used in agricultural, biological and environmental sciences; (2) The measurement methods and indicators of agricultural sustainable intensification are diverse, and the measurement cases are mainly distributed in Europe, Asia, Africa and America; (3) The influencing factors of agricultural sustainable intensification can be roughly divided into four aspects: socio-economic factors, farmers' own characteristics and natural factors, among which population pressure is the potential driving force for agricultural sustainable intensification; (4) The most obvious feature of agricultural sustainable intensification is the reduction of the yield gap. The strategy of implementing agricultural sustainable intensification can be attributed to the effective use of inputs and the adoption of sustainable practices and technologies. Therefore, the implementation path can be summarized as enhancing the effectiveness of external inputs to the agricultural system and optimizing the practice and technology mix within the crop production system. Finally, this paper concludes that research on connotation definition, influencing mechanism, different regional models, incentive mechanism for farmers, impact evaluation and system design of agricultural sustainable intensification should be strengthened in future.
\end{abstract}

Keywords: agricultural; sustainable intensification; measuring method; implementation path; research progress and prospect

\section{Introduction}

The history of agriculture can be seen as a long process of intensification, as society sought to meet its ever-growing needs for food, feed and fiber by raising crop productivity [1]. Coupled with socio-economic development, population growth and growing global food demand, the pressure originated from the resource supply becomes greater, for example, increasingly fierce competition in land inputs, water, energy and other food production, may lead to increased global food price [2], which intensifies the hunger level in developing countries and triggers social and political unrest $[3,4]$. The intensification of crop production in the developing world began in earnest with the Green 
Revolution ${ }^{1}$. Beginning in the 1950s and expanding through the 1960s, changes were seen in crop varieties and agricultural practices worldwide [8], especially in Asia, with having jump-started economies, alleviated rural poverty and having saved large areas of fragile land from conversion to extensive farming [1]. The Revolution was successful in promoting widespread use of new, input responsive seeds together with irrigation, fertilizer and pesticides to increase cereal crop yields and improve food security [3]. Despite the significant increase major crop output in the early stage, the serious negative externalities to natural resources and environment brought by the rapid agricultural productivity have become even worse. Negative externalities such as soil fertility degradation, salinization in irrigated areas, groundwater depletion, increased resistance to pests and weeds and loss of biodiversity seriously restrict agricultural sustainable development in developing countries [9].

In order to cope with the negative impact of traditional agricultural intensification methods, sustainable intensification has replaced the term "green revolution" and become the most commonly used term to date [10]. The premise of agricultural sustainable intensification is that the damage to public interest caused by extensive land use exceeds the benefits of producing additional food on new land, and it endangers environmental sustainability [11,12]. Precisely what should be the supply-side response to the potential threat of global food insecurity? The Foresight Report, again in common with a number of other studies, highlighted the concept of 'sustainable intensification', which was interpreted as producing more food from the same amount of land but with less impact on the environment [4]. Due to people's non-uniform understanding of sustainable intensification and its unclear definition and principle, the definition of sustainable intensification usually depends on the way scholars define. At present, there are many forms of intensification mode, and thus, a number of important features provide a feasible way to clarify the meaning of sustainable intensification.

As a big grain producer and a populous country, China has raised about one-fifth of the world's population with only $7 \%$ of the world's cultivated land. In the process of urbanization and industrialization, cultivated land resources are continuously occupied by construction land. The rural population migration often causes labor force shortage in land cultivation in marginal areas, threatening national food security. Therefore, improving the intensive use of cultivated land is an inevitable way to alleviate the contradiction between current cultivated land resources and future food security [13]. However, the current intensive cultivated land use mostly ignores the carrying capacity of the land ecosystem. At the same time, in order to maximize production, the excessive use of chemical fertilizers and pesticides has paid a heavy ecological cost to food production [14]. Therefore, how to better promote China's cultivated land use pattern from intensive use to environmentally-friendly sustainable intensive use which is, and how to meet the growing food demand at the minimum ecological cost has become a challenge facing China, and one of the urgent problems to be solved [15]. Although the intensive cultivated land use in China has involved the study of environmental benefits [16-18], sustainability of intensive use $[19,20]$, sustainability of farmland ecosystem and Eco-economic zone [21,22], utilization efficiency of production factors [23] and environmental risks of resource input and pollution output [24], systematic and comprehensive research on sustainable intensification of cultivated land use still lacked [25]. Therefore, sorting out and summarizing the research progress of agricultural sustainable intensification abroad is of great significance to the study of sustainable intensive cultivated land use in China.

1 The US Agency for International Development, William Gaud, first proposed the "Green Revolution" [5], but the Green Revolution originated from the cooperation between the Mexican Ministry of Agriculture and the Rockefeller Foundation [6]. In the 1940s, the Rockefeller Foundation's mission to the development of agricultural development in Mexico was linked to the Green Revolution for the first time. In 1943, the Office of Special Studies was established with the Ministry of Agriculture of Mexico to increase the production of major food crops such as corn [7], wheat and soybeans. Subsequent agricultural research projects have developed new high-yielding crop varieties through improved and hybrid research on corn and wheat, resulting in significant increases in production [6]. The Green Revolution, which originated in Mexico, shows how modern crop breeding techniques can help developing countries develop agriculture [6]. The second key event in the start of the Green Revolution was the three-fold to four-fold increase in wheat production, which was the core of the Green Revolution. 
As part of sustainable intensification research, sustainable intensification practices include inputs and practices and the integration of multiple technologies (such as the application of organic fertilizers, soil and water conservation, conservation tillage, legume intercropping and rotations, planting new crop varieties and integrated pest management, etc.), which are a broader meaning of sustainable intensification. Sustainable intensification practices aim to enhance the productivity and resilience of agricultural production systems while using a variety of specific measures in the agricultural production process, while conserving the natural resource base [26]. Research on sustainable intensification practices is mainly concentrated in the African region, with farmers as the research object and their behavior choices in the practice of sustainable intensification [26-28]. At present, research on sustainable intensification covers farmers [28-31], farms [32], agricultural landscapes [33], integrated crop-livestock systems [34], ecosystem services [35,36]. However, systematic review and summary concerning agricultural sustainable intensification still remains blank in the current domestic and international research.

In order to fully understand the current research and trend of agricultural sustainable intensification, this paper uses the information visualization software SciMat to measure and analyze the 962 document data retrieved from the Web of Science core collection database between 1980 and 2019, and along the framework of "connotation definition-measuring method-influencing factors-implementation path", this paper systematically sorts out current research on agricultural sustainable intensification at home and abroad. Based on the main research results, this paper explores the key research areas concerning agricultural sustainable intensification that needs to be improved in the future.

\section{The Conceptual Connotation of Agricultural Sustainable Intensification}

\subsection{The Development of Agricultural Sustainable Intensification}

In order to trace the evolution of agricultural sustainable intensification, the English search databases were searched, including Web of Science, Elsevier, SpringerLink, Google Scholar for keyword and subject search; the search period was "1980-2019", after deduplication and removal of irrelevant data, etc. After that, a total of 962 papers were obtained. By using the time and keyword classification of the literature, we used SciMat to map the evolution of the theme of sustainable intensification over time (see Figure 1). In Figure 1, each node represents the research topic in the field of sustainable intensification in the time zone. The larger the node, the more important it is in the field of sustainable intensification. Therefore, as can be seen from Figure 1, ecosystem, ecosystem service, yield gap and impact are the most important research contents in the development of sustainable intensification. 


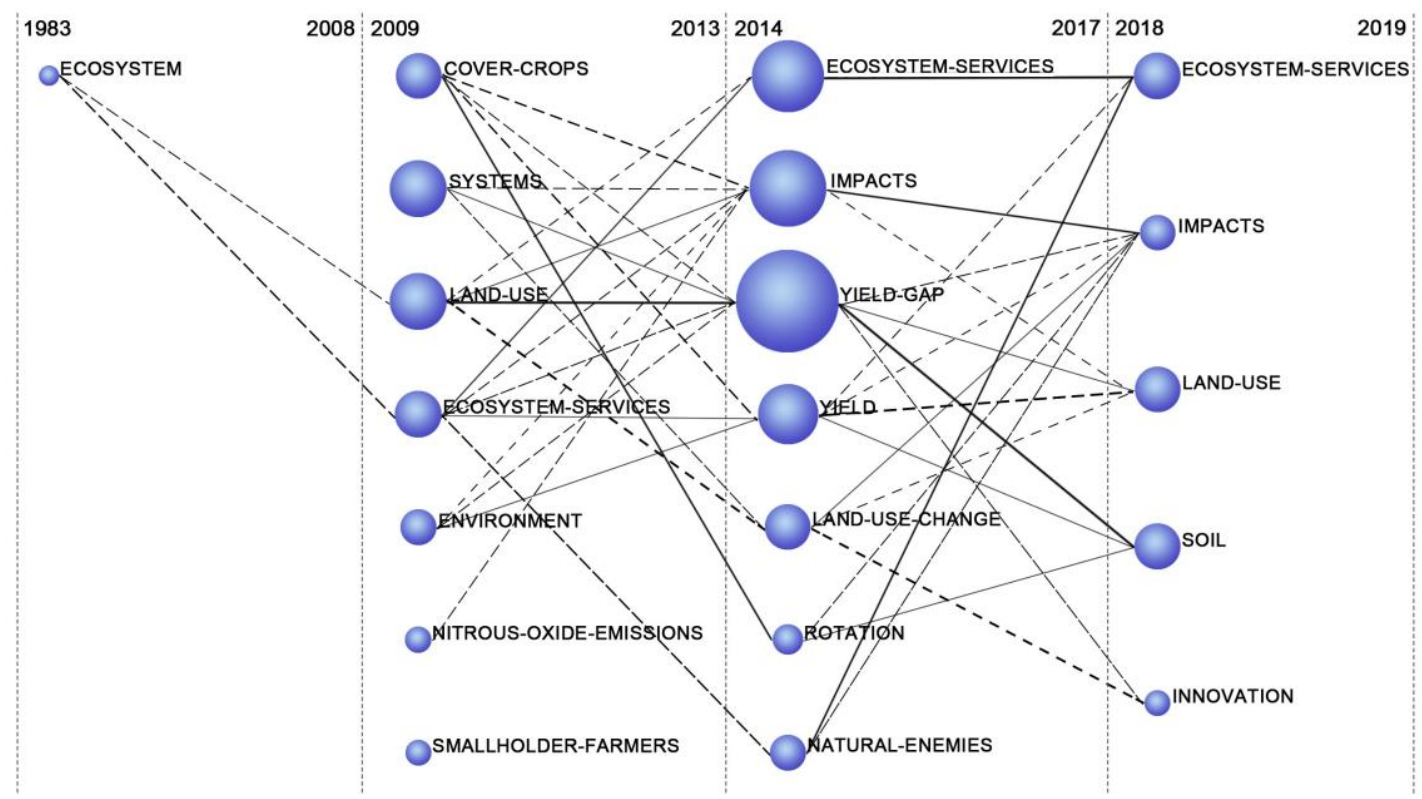

Figure 1. Thematic evolution of the agricultural sustainable intensification research field (1980-2019). Data Source: Web of Science Core Collection.

The sustainable intensification of agriculture was first proposed in 1983, but it caused too much attention. As society faced the challenge of conserving the world population while protecting natural resources, clean water, air and other ecosystem services, until 1997, after putting forward the specific characteristics of sustainable intensification [37], sustainable intensification appeared as a solution to food production. At the same time, the method of protecting the environment has received more and more attention in the field of international agricultural development $[37,38]$.

As the environment and food supply face increasing challenges at present and future, agricultural sustainable intensification has become an important priority for policy makers and international development partners. Nowadays, with increasing attention from scholars, sustainable intensification has become one of the most frequently cited new paradigms of agricultural production. The using frequency of sustainable intensification began to increase in the literature in 2009 and has increased since 2013 (see Figure 2). The reason is that the Royal Society and the Food and Agriculture Organization of the United Nations conducted research on sustainable intensification facing the challenges of growing global food demand [39,40], climate change and tightened global agriculture [41]. At the same time, organizations such as the National Academy of Sciences [42], the Food and Agriculture Organization of the United Nations [40] and the Consultative Group on International Agricultural Research had promoted sustainable intensification as a necessary means for food production in the 21st century [43]. 


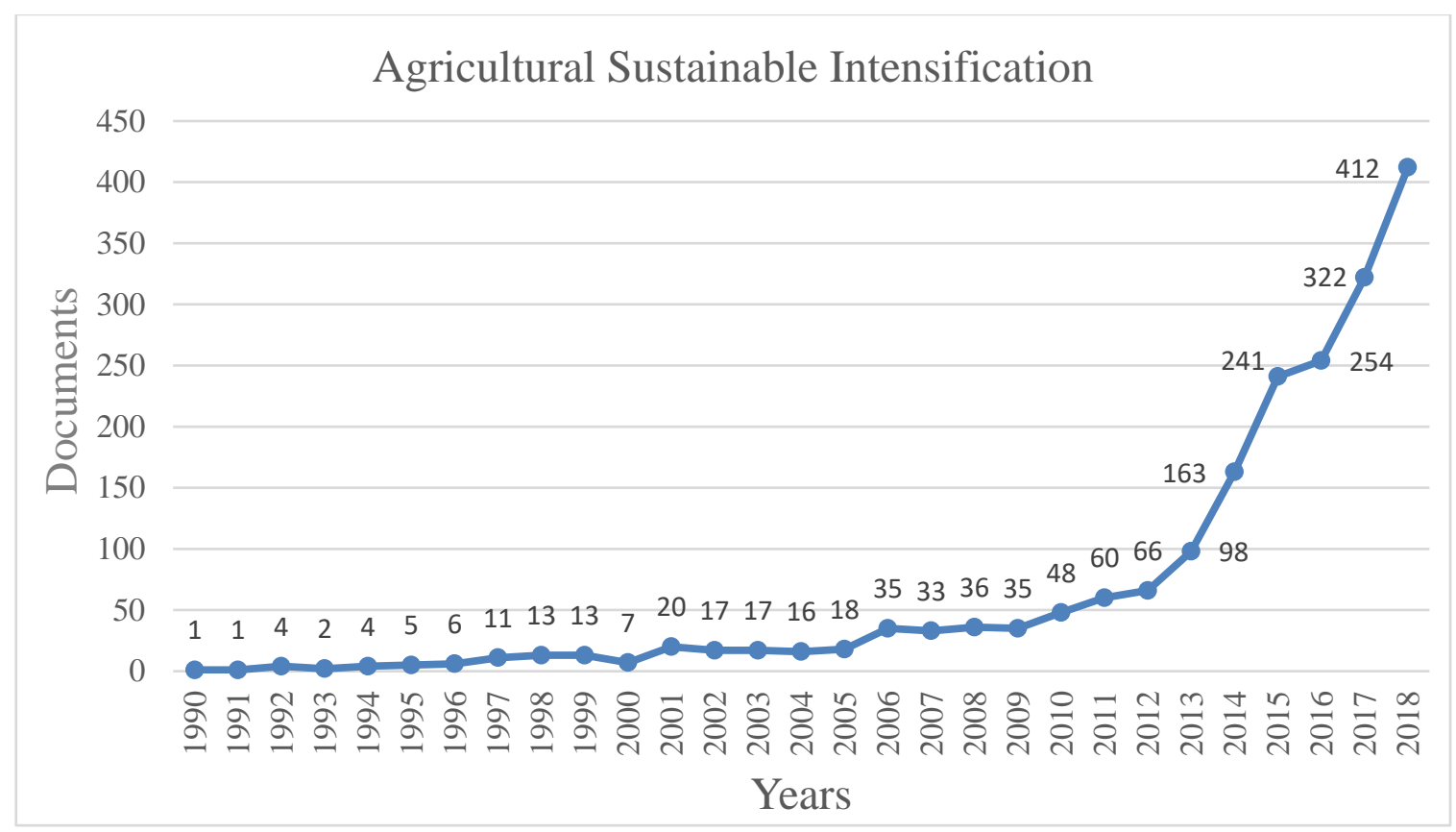

Figure 2. Literature number of agricultural sustainable intensification issued in 1990-2018. Data Source: Web of Science Core Collection.

However, due to the vague meaning and the absence of theoretical basis, it is still regarded as an ideal goal, rather than a set of specific concrete practical measures. Therefore, many scholars look for theoretical alternatives to agricultural sustainable intensification, such as ecological intensification based on ecological theory [38]. Three years after the advent of agricultural sustainable intensification, ecological intensification was first used by Egger to describe an ecological project that maintains soil fertility and builds an agroforestry and animal husbandry system, aiming at protecting soil fertility and establishing the integration of crop, livestock production and forestry on the same land [38]. However, the real intensification of ecological intensification was in the late 1990s. In 1999, from the analysis of agricultural intensification, Cassman (1999) pointed out that the goal of ecological intensification is to "further establish an intensive production system, increase food production and meet environmental quality standard" [44]. After 2000, organizations and research centers around the world began to use and define the term "ecological intensification". The French Centre for International Agricultural Development defined ecological intensification based on ecological theory [45]. The Food and Agriculture Organization of the United Nations has linked organic agriculture to ecological agriculture for the first time in the Organic Agriculture Vocabulary [46]. However, there is no distinction between ecological intensification and sustainable intensification in this document.

Since 2010, the use of term "ecological intensification" has begun to increase significantly in the literature (see Figure 3). The reason is that environmental damage caused by agricultural production needs to be reduced while increasing crop yields [47,48]. Ecological intensification emphasis was placed on increasing the yield ability of major crops and narrowing yield gaps through implementing forms of precision agriculture, relying on scientific breakthroughs in the field of plant physiology, crop ecophysiology and soil science. Later reinterpretations of this concept, particularly in the context of European agriculture [30], attached a definition that borders those of organic or ecological farming. Today, ecological intensification is understood as a means of increasing agricultural outputs (food, fiber, agro-fuels and environmental services) while reducing the use and the need for external inputs (agrochemicals, fuel and plastic), capitalizing on ecological processes that support and regulate primary productivity in agro-ecosystems [30]. Therefore, ecological intensification has gradually evolved from plot scale at which focuses on crop yields and agronomic methods to a multidisciplinary approach to the concept of integrated ecosystem service or biodiversity [10]. Although ecological intensification 
tends to be more diversified in the course of development, the importance of integrating socio-economic improvement with environmental sustainability is highlighted under the framework of agricultural sustainable intensification, which includes the goal of ecological intensification $[34,35]$.

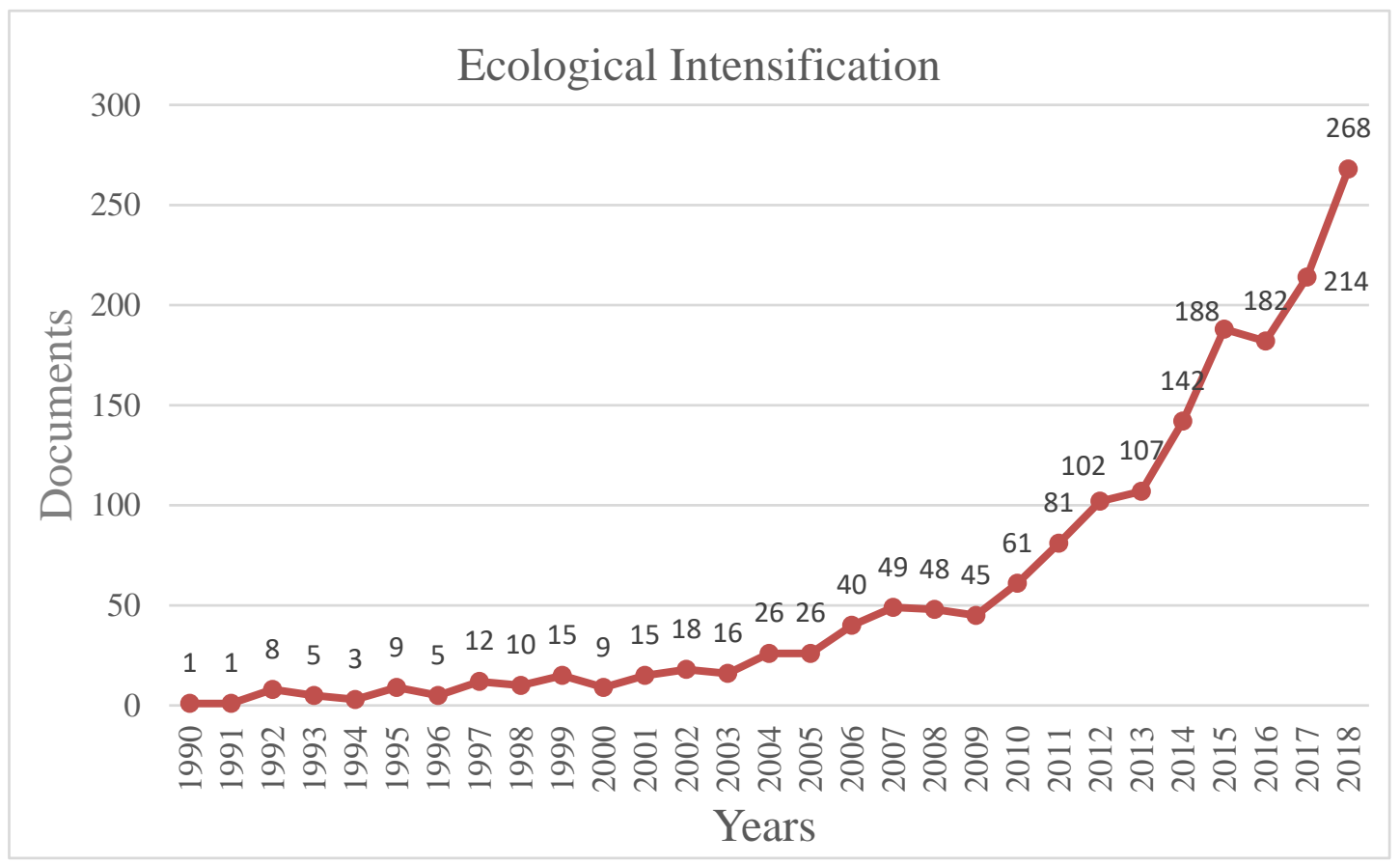

Figure 3. Literature number of ecological intensification issued in 1990-2018. Data Source: Web of Science Core Collection.

\subsection{The Connotation of Agricultural Sustainable Intensification}

For the first time in 1997, Pretty defined agricultural sustainable intensification as "significantly increasing production while protecting natural resources" [37]. Later, Gibon introduced the term into livestock production systems to improve productivity or change product quality by controlling inputs and outputs while maintaining system and environmental integrity [49]. With regard to the definition of sustainable intensification, although Ruben and Lee (2000) defined it from the agricultural economics perspective that focused on increasing land and labor returns while maintaining soil nutrient balance, Pretty (2008) proposed to strengthen the use of natural, social and human assets, and to minimize environmental hazards with combined input and the best available technology [50,51]. Pretty's definition is the most frequently cited and widely used. The Royal Society defines sustainable intensification as "increasing production without affecting the environment or cultivating more land" [39]. Food and Agriculture Organization of the United Nations (FAO) has given the latest and most widely cited definition of sustainable intensification as "to produce more products from the same region while saving resources, reducing negative impacts on the environment, enhancing natural capital and ecosystem services flows" [40]. It should be noted that other strategies such as land sparing and land sharing are also used to address how to meet rising food demand at the least cost to biodiversity. land sharing involves integrating biodiversity conservation and food production on the same land, using wildlife-friendly farming methods [52]. Land sparing consists of separating land for conservation from land for crops, with high-yield farming facilitating the protection of remaining natural habitats from agricultural expansion [52]. However, the increases in crop yields do not guarantee land sparing [53], and land sharing schemes do not guarantee benefits to biodiversity on farmed land [54].

Today, sustainable intensification has become a generally accepted framework for researchers, and the generally accepted interpretation is to increase unit production input while reducing environmental 
impact [55-62]. Its main purpose is to increase the utilization efficiency of agricultural resources, thereby further achieving agricultural intensification by increasing yield per hectare [63]. Therefore, combined with existing research, key elements such as characteristics/definitions, principles and practices of agricultural sustainable intensification are summarized (see Table 1).

Table 1. Characteristics/definitions, principles and practices of agricultural sustainable intensification.

\begin{tabular}{|c|c|c|}
\hline & Agricultural Sustainable intensification & Source \\
\hline \multirow{5}{*}{ Characteristics/Definitions } & $\begin{array}{l}\text { 1. Significantly increase production while protecting } \\
\text { natural resources. }\end{array}$ & [37] \\
\hline & $\begin{array}{l}\text { 2. Control inputs and outputs of livestock production } \\
\text { systems to increase productivity or production while } \\
\text { maintaining system and environmental integrity. }\end{array}$ & [49] \\
\hline & $\begin{array}{l}\text { 3. Improve the return of land and labor, and maintain soil } \\
\text { nutrient balance. }\end{array}$ & {$[50]$} \\
\hline & $\begin{array}{l}\text { 4. Strengthen the use of natural, social and human assets, } \\
\text { and use the best available technologies and inputs to } \\
\text { minimize environmental damage. }\end{array}$ & [51] \\
\hline & $\begin{array}{l}\text { 5. Increase production without affecting the environment } \\
\text { and not cultivating more land. }\end{array}$ & {$[39,57]$} \\
\hline \multirow{4}{*}{ Principles } & $\begin{array}{l}\text { 1. Reduce land use and increase the use of renewable } \\
\text { resources such as labor, light and knowledge to } \\
\text { increase production. }\end{array}$ & {$[56,64]$} \\
\hline & $\begin{array}{l}\text { 2. Improve resource use efficiency, optimize the } \\
\text { application of external inputs, reduce the negative impact } \\
\text { of food production on the environment, and narrow the } \\
\text { output gap. }\end{array}$ & {$[37,65]$} \\
\hline & 3. Improve the use of crop varieties and livestock breeds. & {$[50,51]$} \\
\hline & 4. Reduce food waste and increase productivity. & [55] \\
\hline \multirow{6}{*}{ Practices } & $\begin{array}{l}\text { 1. Conservation tillage, crop rotation, and using biofouling } \\
\text { and residual plastic film to cover soil. }\end{array}$ & [10] \\
\hline & $\begin{array}{l}\text { 2. Use beans, cover crops and harvest crops in } \\
\text { crop rotation. }\end{array}$ & [12] \\
\hline & 3. Integrated pest management. & [37] \\
\hline & $\begin{array}{l}\text { 4. Soil and water conservation, and effective management } \\
\text { of soil health. }\end{array}$ & {$[1,10]$} \\
\hline & $\begin{array}{l}\text { 5. Plant genetic resources protection, and } \\
\text { improved varieties. }\end{array}$ & [1] \\
\hline & $\begin{array}{l}\text { 6. Water management, fertigation, inadequate irrigation, } \\
\text { supplementary irrigation. }\end{array}$ & [1] \\
\hline
\end{tabular}

\subsection{The Relationship and Difference between Agricultural Sustainable Intensification and} Ecological Intensification

From the conceptual connotation and development history of agricultural sustainable intensification and ecological intensification, ecological intensification is more focused on the use of ecological processes, ecosystem services and resource utilization efficiency. In contrast, with a primary focus on optimal management of inputs and outputs in the production process, resource use efficiency is less expressed in terms of sustainable intensification. Nevertheless, despite the varying wordings, the definitions of ecological intensification and agricultural sustainable intensification overlap strongly in key elements such as increasing production and minimizing environmental impacts [7]. As the overall framework of intensification, sustainable intensification has far more conceptual connotations 
than ecological intensification. It emphasizes on environmental issues as well as rational production and consumption. However, ecological intensification pays more attention to ecological principles and environmental sustainability [66].

The conceptual overlap of agricultural sustainable intensification and ecological intensification leads to the confusion between them to some extent. In many cases, sustainable intensification represents a relatively broad category that only addresses sustainability issues to some extent, so most current agricultural practices fall into this category [10]. However, ecological intensification brings a clearer definition in general. For example, ecological intensification emphasizes the understanding and intensification of biological and ecological processes and functions in agro-ecosystems, and extends its scope to landscape use and ecosystem services. Therefore, this paper summarizes the key components of the characteristics/definitions of ecological intensification (see Table 2).

Table 2. Key characteristics/definitions of ecological intensification.

\begin{tabular}{|c|c|c|}
\hline & Ecological Intensification & Source \\
\hline \multirow{5}{*}{ Characteristics/Definitions } & $\begin{array}{l}\text { 1. Strengthen the production system to increase grain } \\
\text { production while minimizing the negative impacts on } \\
\text { the environment. }\end{array}$ & [44] \\
\hline & 2. Improve the efficiency of investment and resource use. & {$[30,45]$} \\
\hline & 3. A system that utilizes ecological processes and services. & {$[45,66]$} \\
\hline & $\begin{array}{l}\text { 4. Increase food production while reducing external inputs } \\
\text { and minimizing negative impacts on the environment, and } \\
\text { using ecological processes and ecosystem services from } \\
\text { plot to landscape scale. }\end{array}$ & [10] \\
\hline & $\begin{array}{l}\text { 5. Reduce production gaps while reducing external inputs; } \\
\text { rely on local agricultural system knowledge. }\end{array}$ & [67] \\
\hline
\end{tabular}

\section{Research Progress in the Measurement of Agricultural Sustainable Intensification}

\subsection{Measurement Index System for Agricultural Sustainable Intensification}

The connotation of agricultural sustainable intensification is diverse, so constructing an index system becomes a commonly used method to measure whether the study object realizes agricultural sustainable intensification. The evaluation result analysis helps clarify the specific measures to achieve agricultural sustainable intensification and improve the degree of sustainable intensification of research objects. Besides, it has great guiding significance for the formulation of corresponding policy strategies.

From the perspective of sustainable intensification indicators, Smith et al. (2017) divided sustainable intensification assessment indicators into five areas: productivity, economic sustainability, environmental sustainability, social sustainability and human well-being [68]. Stachetti et al. (2018) evaluated the ecological intensification level of coconut production in Brazilian farms from five dimensions: landscape ecology, environmental quality, social and cultural values, economic values, and management [69]. Mahon et al. (2018) identified sustainable intensification indicators from the perspective of UK stakeholders. Based on generally accepted sustainability principles, they evaluated these subsystems from seven subsystems: resource systems, resource units, governance, resource users, interactions, outcomes, and environment [70]. Liao and Brown (2018) believes that when assessing the synergies generated by agricultural sustainable intensification, improving farmers' livelihoods, maintaining food production and ecosystem services are indispensable components [61]. In the Appendix A, Table A1 summarizes the current indicators for measuring agricultural sustainable intensification.

In the perspective of the application of sustainable intensification indicators, taking the three frameworks of Response-Induced Sustainability Evaluation, Sustainability Assessment of Food and Agricultural systems as a concept of agricultural management, Slätmo et al. (2017) analyzed farms' 
sustainability [71]. Snap et al. (2018) applied the Sustainable Intensification Indicators Framework to assess the value of Maavian corn-bean diversification and integrated soil fertility management techniques in Africa [72].

From the perspective of measuring sustainable intensification by indexes, Gadanakis (2015) evaluated the level of sustainable intensification of farms in the British east Anglian basin by measuring the ecological efficiency index. Based on it, the characteristics of agricultural systems that may affect ecological efficiency are identified, so as to ensure the balance between sustainable production and intensification [62].

\subsection{Measuring Method of Agricultural Sustainable Intensification}

From the farmer scale, Ndiritu et al. (2014) used a multivariate probability (MVP) model to verify whether systematic gender differences exist in Kenya's sustainable intensification practices [27]. David et al. (2016) used the choice experiments (CE) approach to assess smallholders' behavioral preferences in adopting sustainable intensification practices [28].

From the farm scale, Rodrigues et al. (2010) used the apoia-novorural method to assess the level of agricultural sustainability and ecological intensification respectively [73]. Bezlepkina et al. (2011) pointed out that it is particularly important to use a higher level of integrated assessment (IA) to analyze the level of sustainable intensification in other sectors [74]. Based on different farm types, Firbank et al. (2013) measured sustainable intensification level through a comparative analysis between agricultural production changes and environmental variables, that is, increased food production without reduction in ecosystem services [64]. Sánchez-Escobar et al. (2018) used education return on investment (EROI) and activity-based costing $(\mathrm{ABC})$ methods to measure the sustainable intensification level of agricultural systems at farm scale [75].

From a regional perspective, Ndiritu et al. (2014) used a multivariate probability model to explore the combination of sustainable intensification inputs in southeastern Africa and assessed agricultural sustainable intensification [27]. Yami et al. (2017) used the policy arrangement approach (PAA) method to assess the policy support level for sustainable crop intensification in east Africa [76].

In general, in spite of the diverse measuring methods for agricultural sustainable intensification most focus on model-building analysis at the farm level. The farmer level measurements mainly focus on the practice of agricultural sustainable intensification, and the regional level measurements mainly focus on the performance at a wider scale.

\subsection{Cases of Agricultural Sustainable Intensification Measurement}

The geographic distribution map of global agricultural sustainable intensification studies was drawn using the software ARCGIS 10.2 (see Figure 4). In the figure, the numbers represent the number of publications on agricultural sustainable intensification between 1990 and 2018. According to Figure 4 and the publications of various countries in the field of sustainable intensification, the research cases of agricultural sustainable intensification evaluation are mainly distributed in Europe, Asia, Africa and the Americas. The evaluation scale covers towns [77], farms and farmers [28,64,78]. Among them, Europe mainly involves Britain [62,64,79], France and the Netherlands [80,81]. Asia is concentrated in India [82], while Africa is mainly concentrated in sub-Saharan Africa [83], including Ethiopia [26,76], Kenya and Malawi [27,33]. In the Americas, it is mainly distributed in the United States in North America and Canada [33,38], Brazil in South America and other tropical regions [34]. On the whole, most of these areas are mountainous and populous. 


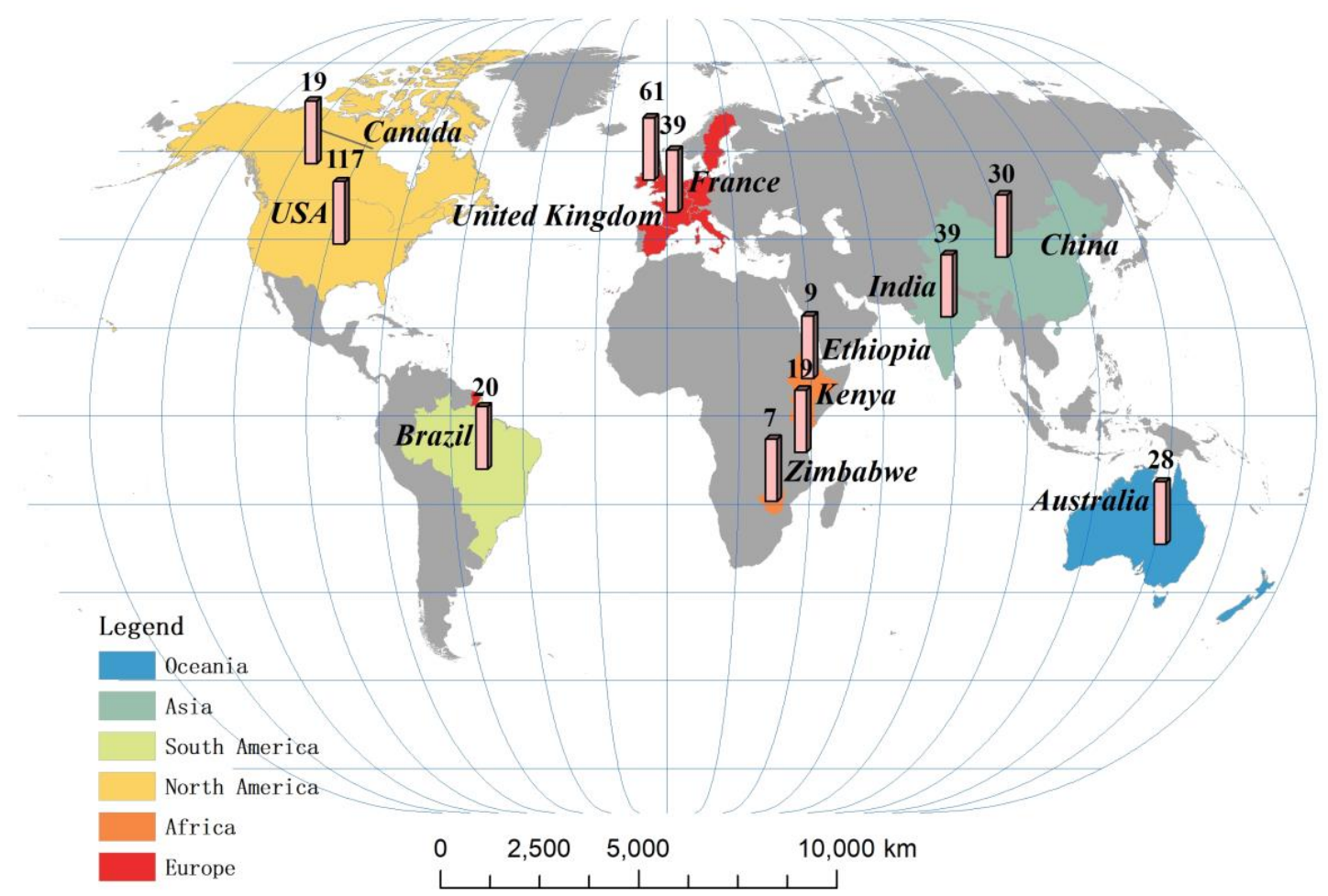

Figure 4. Visualization of the geographical distribution of literatures on global sustainable intensification practices. Data source: Web of Science Core Collection.

\section{Research Progress in Research on Influencing Factors of Agricultural Sustainable Intensification}

\subsection{Changes in Socio-Economic Factors are the Main Factors Restricting Agricultural Sustainable Intensification}

According to the existing research, the factors affecting the realization of sustainable intensification can be summarized as follows: (1) socio-economic factors; (2) farmers' own characteristics; (3) natural environmental factors.

The socio-economic factors affect farmers and participants in other private sectors' incentives to invest in sustainable intensification in macroscopic. Achieving higher crop output prices restricts the small farmers' adoption of sustainable intensification [84]. For example, Woelcke's (2010) research in eastern Uganda showed that it was critical to motivate smallholders to move towards sustainable crop production by overcoming information gaps, increasing crop output prices, increasing market access to information and reducing transportation costs [85]. Cortne et al. (2019) research on the crop-livestock integrated system in the Brazilian Amazon pastures showed that market access, product prices, pasture facilities, credit access and other factors severely restrict farmers' adoption of the system [34]. The agricultural policies of East African countries and Uganda's national development plan indicated that the imperfect infrastructure such as road networks limited agricultural participants' implementation of sustainable crop intensification [76].

Sustainable intensification depends on how farmers (farmers and their families) live with natural, ecological, social, economic and political environments and rely on them to achieve sustainable living [86]. At present, many scholars explore the impact of different farmer characteristics on agricultural sustainable intensification from the perspective of farmers. Indicators reflecting the characteristics of farmers mainly include family size, age, gender, education level and degree of concurrent employment, etc. $[27,60]$. Among them, farmers with older ages and education level are less likely to adopt agricultural sustainable intensification practices and have a negative inhibitory effect on sustainable intensification [27]. The more families and the more part-time farmers are, the 
more likely they are to adopt agricultural sustainable intensification practices, which will positively promote sustainable intensification. It should be pointed out that the gender differences among heads of households in the characteristics of farmers have received extensive attention in the study of agricultural sustainable intensification in Africa. In particular, gender differences within the family, kinship networks and social networks contribute to the heterogeneity of technology adoption in soil and water conservation, field replanting, minimum tillage and crop diversification (cover crops, intercropping and crop rotation) [26]. For example, taking gender differences as the dominant factor, Ndiritu et al. (2014) analyzed women's sustainable intensive farming practices and technology adoption in Kenya under different rights constraints [27]. The study showed that gender differences existed in sustainable intensive farming practices such as minimum tillage, or adoption of livestock and poultry manure. Himmelstein et al. (2016) argued that in the technology design of achieving sustainable intensification, some factors which are often overlooked in technology design or developing agricultural programs and sustainable agricultural practices, such as preferences, needs and women farmers' roles, should be taken into consideration [87]. Therefore, Snapp et al. (2018) explicitly considered women's technology preference in the framework of sustainable intensification indicators. The study found that women were twice as likely as men to adopt other sustainable intensification technologies in leguminous plant systems [72].

In terms of natural factors, most studies have shown that climate change, elevation, slope, soil organic matter, precipitation and land quality also affect the adoption of agricultural sustainable intensification [58-60]. Among them, the slope, soil organic matter and land quality influence the soil resilience and influence the sustainable intensification practice on the land [59]. Climate change has a great impact on temperature changes, rainfall changes and extreme events in low-altitude areas, leading to greater risks in agricultural production environments and affecting farmers' adoption of sustainable intensification practices. For example, in order to adapt to climate change, Uganda's coffee production shifted to high altitudes, offering an opportunity for sustainable intensification of coffee agro-ecosystems at different altitudes [88]. Table 3 summarizes the influencing factors of agricultural sustainable intensification in different countries at varied scales.

Table 3. Influencing factors of agricultural sustainable intensification in different countries at varied scales.

\begin{tabular}{lllc}
\hline \multicolumn{1}{c}{ Study Area } & Scale & \multicolumn{1}{c}{ Influencing Factor } & Source \\
\hline Brazilian Amazon & farm & $\begin{array}{l}\text { market access, product prices, ranch facilities, credit access, } \\
\text { lack of marketing options. }\end{array}$ & [34] \\
\hline Central and southern Malawi & farmer & $\begin{array}{l}\text { low soil fertility, population density, market access, } \\
\text { imperfect infrastructure, farmers' preferences. }\end{array}$ & [28] \\
\hline Central Malawi & farm & $\begin{array}{l}\text { gender preferences, weather conditions, population } \\
\text { density, crop prices, farm size. }\end{array}$ & [72] \\
\hline Central Andes & region & $\begin{array}{l}\text { climate change, planting disturbances, over grazing, } \\
\text { mining activities. }\end{array}$ & [89] \\
\hline Eastern and southern Africa & plot & $\begin{array}{l}\text { market access, agricultural extension services, information } \\
\text { scarcity, technology adoption. }\end{array}$ & [26] \\
\hline Eastern and western Kenya & farmer & $\begin{array}{l}\text { gender differences, technology gaps, market access, land } \\
\text { quality, credit opportunities, extension services. }\end{array}$ & [27] \\
\hline East Africa (Ethiopia, Kenya and Uganda) & country & $\begin{array}{l}\text { lack of investment incentives, insufficient agricultural } \\
\text { extension systems imperfect infrastructure. }\end{array}$ & [76] \\
\hline Eastern Uganda & farmer & $\begin{array}{l}\text { population pressure, market information, price volatility, } \\
\text { climate change, low yield, farmer livelihood. }\end{array}$ & [88] \\
\hline Eastern Kenya & farm & $\begin{array}{l}\text { population density, land quality, access to information, } \\
\text { farmers' behavior, climatic conditions. }\end{array}$ & [90] \\
\hline Germany & plot & $\begin{array}{l}\text { population pressure, food demand, soil organic matter, } \\
\text { slope, soil depth. }\end{array}$ & [58] \\
\hline Sub-Saharan Africa & farmer & $\begin{array}{l}\text { soil fertility, population pressure, production gap, } \\
\text { livelihood strategy, market access. }\end{array}$ \\
\hline Southern Kenya & village & $\begin{array}{l}\text { population density, crop price fluctuations, rainfall. } \\
\text { fropical reunion }\end{array}$ & $\begin{array}{l}\text { population pressure, food demand growth, environmental } \\
\text { stress, farm type. }\end{array}$ \\
\hline [29]
\end{tabular}

Note: Table A2 in the Appendix A excerpts papers that have made significant contributions to the study of agricultural sustainable intensification. Including authors, journal, publication year, number of indicators used, nature of indicators, scale of application, influencing factors, etc. 


\subsection{Population Pressure is a Potential Driver of Agricultural Sustainable Intensification}

The shortage of land resources caused by population pressure forced farmers to adopt sustainable intensification [93]. Overpopulation contributed to the increased demand for food, and land competition with other human activities such as urbanization intensified the restrictions of using new farming land $[27,91]$. Therefore, land resources are overused to produce food to meet human needs. The decline in productivity caused by soil erosion, soil pollution and land degradation, and degraded soil carbon sequestration capacity is forcing a dramatic shift from sustainable agriculture to sustainable intensification [91,94].

Population pressure not only affects farmers' behavioral decisions in agricultural production at the household level, but may also jeopardize national food security. For example, for families with less land, as the family population increases, it is more likely to adopt sustainable intensification practices on a particular land, including legume intercropping, conservation tillage, improved varieties and fertilization [93]. In addition, the vulnerability of small farmers is highlighted in their ability to resist risks. Low crop yields caused by climate change have a direct negative impact on per capita income. Falconnier et al. (2017) research in Southern Mali showed that policies interventions for sustainable intensification needed to be integrated with farmers' practice of intensification to make the entire agricultural population exceed the poverty line [31].

\subsection{Agricultural Sustainable Intensification is the Combined Result of Multiple Factors}

The clustering network diagram was drawn by using SciMat to study the theme of agricultural sustainable intensification (see Figure 5). The "Impact" theme in Figure 5 represents the influencing factors of agricultural sustainable intensification. There are 11 nodes and 11 connections in the figure. The important nodes connected internally are "Populations", "Technology" and "Smallholder". The theme of agricultural sustainable intensification is closely linked to other themes, indicating that agricultural sustainable intensification is driven by many factors.

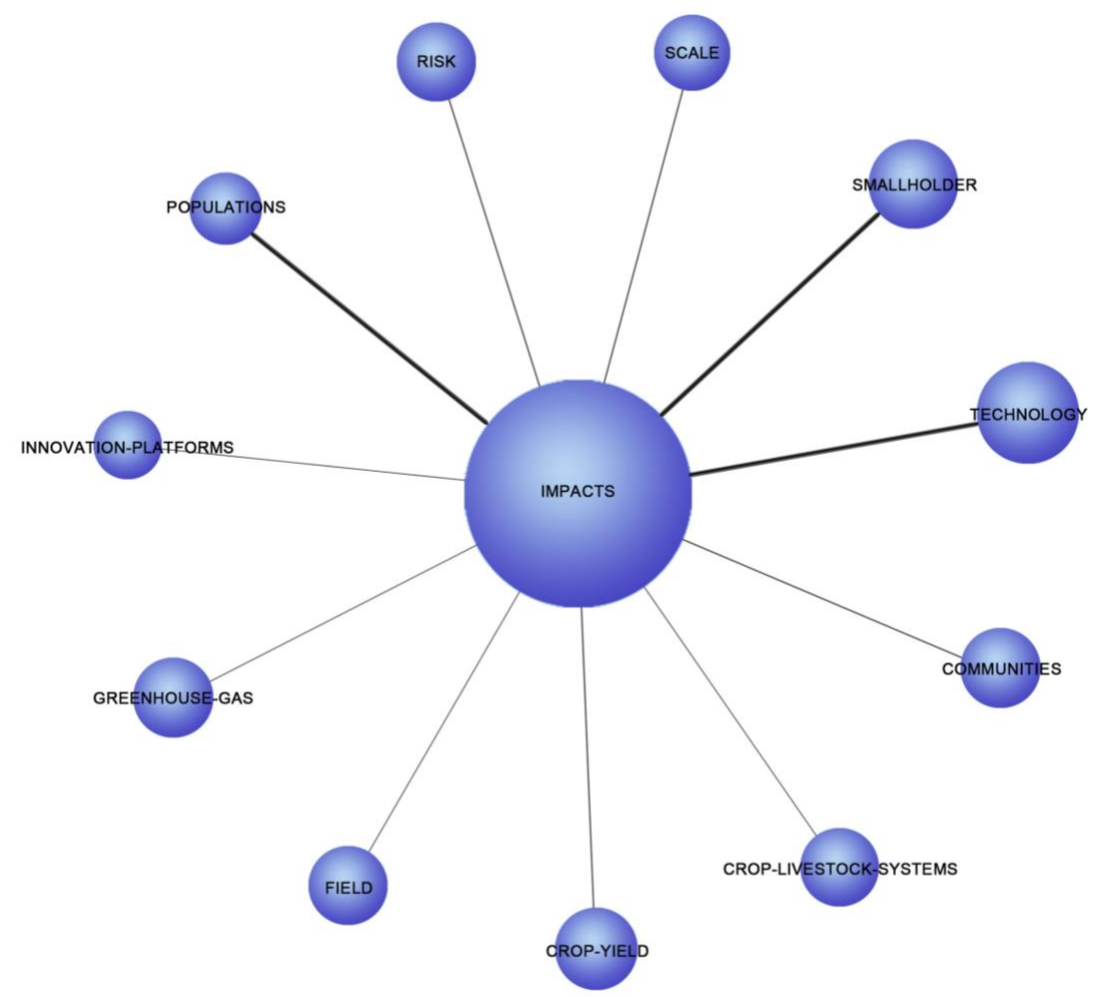

Figure 5. Clustering network diagram of the influencing factors of agricultural sustainable intensification. Data source: Web of Science Core Collection. 
Human activities occur at any time within the framework of the triple interconnection and interaction of natural systems, economic systems and institutional systems [95]. It is also unavoidable that human activities can lead to agricultural sustainable intensification that is unable to sustain human survival. For example, sustainable intensification measures may affect farm profitability [60], so implementing these measures should take economic sustainability into account. Even if they are economically viable, they may encounter other challenges, especially changes in the natural environment. In some cases, due to limited water availability and seasonal rainfall imbalance, it may be challenging to reduce the yield gap [96]. Integrating environmental changes into large-scale and coordinated sustainable intensification practice project needs national and local institutional support [88]. For example, strengthen infrastructure construction, providing technical and land support for water storage in rainy season for use in dry season or water collection for irrigation areas, and enhance farmers' access to resources, especially land, water, credit and knowledge, all need to improve the coordination and communication between all national sub-sectors, from production to processing to marketing $[60,88]$. Agricultural extension services and technological innovations that adapt to new policies and systems are feedbacks of agricultural production through sustainable intensification practices. With population growth, climate change, energy scarcity, degraded natural resources and market globalization, people are forced to rethink policies and institutions regarding crop sustainable intensification production [97]. Therefore, sustainable intensification is a combined result of various drivers such as social and economic development, policy system, natural factors and technological development.

\section{Research Progress on the Realization Path of Agricultural Sustainable Intensification}

\subsection{Main Characterization of Agricultural Sustainable Intensification}

From the theme evolution map of agricultural sustainable intensification research (see Figure 1), the yield gap has attracted much attention in recent agricultural sustainable intensification research. Figure 6 is a clustering network diagram of the yield gap, and the nodes with higher correlation are "Land-use", "Soil" and "Systems". Today, many scholars believe that the most obvious manifestation of agricultural sustainable intensification is to shorten the production gap [30,98], that is, increase food production. There are two ways to increase food production, namely, through external input and internal optimization. Aiming at increasing agricultural productivity, measures related to external inputs include improving road infrastructure and market access, providing technical support and extension services to farmers [99]. Achieving sustainable intensification by improving some external facilities is a common practice in developed countries in the early days. However, due to the diversified regional and socio-economic conditions, the development strategy of providing external services is still the main measure to promote agricultural sustainable intensification in developing countries. Currently, the gradual shift towards reducing external inputs and increasing the intensification degree of internal system has been recognized as the most common sustainable intensification practice [10]. These include conservation tillage, crop rotation, intercropping of beans and other crops, and soil and water conservation. 


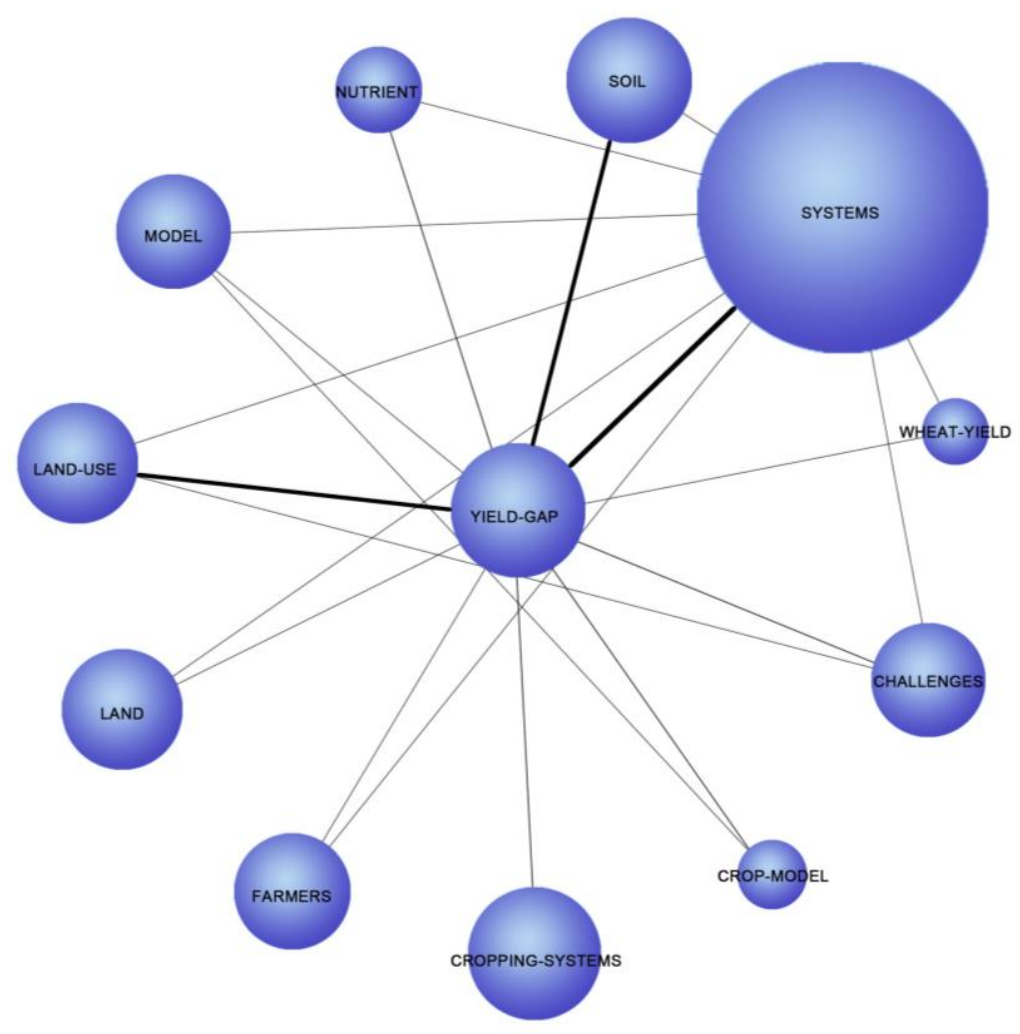

Figure 6. Yield gap of the agricultural sustainable intensification theme cluster network diagram. Data source: Web of Science Core Collection.

\subsubsection{Internal Optimization Path for Agricultural Systems}

The lack of money restricted traditional farmers from purchasing advanced equipment, chemicals and patented seeds to spread the green revolution, which aims to increase yields [94]. Moreover, due to insufficient attention to the crop insurance system strategy, for small farmers, the sustainable intensification of crop production is a high-risk industry. This situation may force small farmers to adhere to the traditional farming practices, thereby limiting local innovation and the transformation of farming systems. Therefore, changes in planting patterns and new ideas provide opportunities to achieving sustainable intensification by improve external agricultural inputs and strengthening endogenous agricultural systems [94]. In order to quantify the opportunity to increase production, from the perspective of farmers' supply and consumption demand, through the use of multiple cropping, no-till, non-sufficient irrigation, abandoning luxury crop cultivation and reducing food waste, the agricultural production system can be continuously intensified [60]. Creating production gaps, different agricultural production methods affect natural resources, especially for heterogeneous small farm landscapes [29]. Therefore, the way to achieve sustainable intensification needs to take the flexibility in practice into consideration, such as the diversity of agricultural ecological conditions, farmers' endowment, farming system and social and economic conditions [93]. However, in the process of agricultural landscape monitoring, too much attention is paid to food supply and demand and crop productivity, while the analysis of ecosystem services and social ecological effects is ignored $[35,60]$. Therefore, in face of climate change, Uganda coffee growers explored ecologically adaptive paths as effective strategies to achieve sustainable intensification and adapt to climate change [88]. In a particular study area, if forests are taken as inputs for energy and nutrients in local agricultural systems, retaining forests in agricultural landscapes seems to be a viable way to achieve sustainable intensification [33]. However, in the tropics, the agricultural landscape changes caused by the expansion of pineapple planting, have a negative impact on the ecological environment to some extent. Therefore, exploring a land use pattern that balances agricultural development and biodiversity conservation and 
preserves spatial and economic diversity, is an important initiative to promote agricultural sustainable development [100].

\subsubsection{External Input Path for Agricultural System}

Optimizing external inputs of agricultural systems is critical to sustainable intensification. Increasing productivity requires access to agriculture, credit, market, agricultural knowledge and information, agricultural extension services and improved infrastructure [29,35]. Therefore, a large number of studies have focused on reducing agricultural cost or environmental pressure by effectively utilizing natural, chemical and human resources. It is highlighted that agricultural production efficiency can be improved by reducing resource input or increasing output to achieve sustainable intensification [101]. Technologies aiming at reducing agricultural inputs covers nutrient management technology to improve fertilizer utilization efficiency [102], carbon related measures, nitrogen, phosphorus balance and loss [103], new methods for improving irrigation water efficiency, application of pesticides, antibiotics and green manure seeds [104,105]. Combined with other practices, the improvement and application of these new methods are closely related to the agricultural sustainable intensification. In the study of sustainable intensification in Africa, agricultural extension services, access to credit and market are often used as explanatory variables of sustainable intensification [67]. The skills of extension staff, information quality provided to farmers, stable market channels, access to input information and credit services have a positive impact on farmers' adoption of sustainable intensification practices [26]. However, the disjointedness between government's policy formulation for promoting sustainable intensification and the multiple restrictions faced by farmers in production process may bring greater risks to small farmers' planning and investment behaviors related to sustainable intensification of agricultural production. As risks exacerbated by climate change, small farmers tend to avoid risk avoidance and pursue short-term investment returns. Therefore, from the perspective of risk management and sustainability, the establishment of a risk-resistant production system is the key to promoting sustainable intensification [29]. With the improvement of external input technology, human resources in agricultural production systems need to be adjusted accordingly, such as improving knowledge management and labor productivity [101]. The mutual knowledge exchange between farmers expands the adoption scope and promotes the spontaneous implementation of sustainable intensification practices. Therefore, the successful application of crop-production sustainable-intensification will depend on farmers' wise technology choice and consideration between short-term and long-term impacts requiring farmers to fully understand the agro-ecosystem functions' role [1]. The interaction between socio-economic and technological conditions largely influences the transition path of agricultural systems to sustainable intensification, and determines the scale that sustainable intensification can achieve.

\subsection{The Practice Path for Agricultural Sustainable Intensification}

Sustainable intensification practices depend on regional environments, historical developments and current land-use practice, thus the practice forms are different in different places and agricultural systems [101]. Research on farmers of sustainable intensification practice focuses on the complementarity analysis between multiple or single agricultural technologies that measure sustainable intensification practices in different countries, and the tradeoff quantifying of sustainable intensification practices [26]. A comprehensive set of four sustainable intensification measures at the regional scale, including multiple cropping, no-till, under-irrigation and abandonment of luxury crops, may save land, water and soil resources while increasing food security. Through similar interventions, sustainable intensification in countries with similar socio-economic characteristics can be promoted [60]. For example, the soil management system designed to protect and increase soil organic matter in Latin America, which increases soil organic matter through the use of carbon-rich coverings, permanent soil coverings and no-till soil surfaces, has become an important component of crop sustainable intensification [1]. In Africa, measures such as biological nitrogen fixation, crop 
fallow rotation, and protective coverings are used to achieve sustainable intensification of agricultural systems. However, sustainable intensification of the planting system focuses on studying the resource use efficiency of external inputs and ways to make full use of renewable natural resources within the system to reduce the impact on the environment $[64,106,107]$. In the integration of production activities, crop-livestock integration is considered as a possible solution to the sustainable intensification of agricultural systems [92]. It is important to improve agricultural productivity through synergies between nutrient flows and material flows of different natures, and to coordinate land use requirements and input-output ratios between farmland and pastures to achieve sustainable intensification of crop-livestock integrated production system [34].

\section{Conclusions and Prospects for Agricultural Sustainable Intensification}

Along with the debate on the future of food, environment and agriculture, agricultural sustainable intensification has developed to this day. The concept of "sustainable intensification" is evolving and it seeks to capture the advantages of traditional agriculture and organic agriculture while minimizing their deficiencies (such as the high input of traditional agriculture and the low output of organic agriculture). Moreover, reduce damage to the ecological environment and its service functions, thus bridging the gap between the two and protecting the ecological environment. This has important reference significance for promoting the transfer of arable land use methods that are overburdened and over-invested in China's agricultural production system to agricultural sustainable intensification. The research on the measurement of agricultural sustainable intensification has formed a basic evaluation index system on the multi-perspective level. Moreover, the measurement methods are diverse, and the model construction analysis is mostly carried out from the farm level. The case studies of agricultural sustainable intensification are mostly concentrated in Africa and developed countries, and there is a lack of measurement and case studies of agricultural sustainable intensification for developing countries, especially China. The main factors affecting the sustainable intensification of agriculture are socio-economic factors, farmers' own characteristics and natural factors. The realization path is to enhance the effectiveness of external inputs of agricultural systems and optimize the practice and technology combination within the crop production system. China is a very typical small-scale peasant country in the world. It is necessary to explore the factors affecting small-agricultural countries to achieve agricultural sustainable intensification and the realization of the path. Although agricultural sustainable intensification research has achieved rich research results in theory and practice, there are still many problems in this field that need to be solved urgently. It is necessary to work from the following aspects.

\subsection{Clarification of the Connotation of Agricultural Sustainable Intensification}

The connotation of sustainable intensification is heterogeneous in different perspectives. Although many institutions and organizations recognize sustainable intensification as a means of increasing food production and meeting global food demand in the 21st century, the agricultural technologies involved are not described in any detail. It is still unclear that what sustainable intensification means and how to use it [38]. In Europe, as a response to increased environmental pressures, sustainable intensification has been increasingly highlighted in policy development. The New Zealand agricultural sector has embarked on a path towards ecological sustainability. However, compared with agricultural, biological and environmental science, sustainable intensification is not representative enough in economics and social sciences, hindering the overall analysis and consensus of sustainable intensification [101]. At present, sustainable intensification is still treated as a general concept with few metrics and is used ambiguously on multiple levels [38]. Therefore, in order to accurately measure sustainable intensification and reach a consensus on the concept, it is imperative to construct standards and a unified evaluation index system to accurately measure sustainable intensification. In addition, introducing or developing more scientific research methods and a more 
realistic theory, including a clear theoretical basis, clear goals, and specific actions to achieve these goals, will be an important issue to be resolved in the next step.

\subsection{Study on Agricultural Sustainable Intensification Models in Different Regions}

Due to the different natural environments and socio-economic conditions in different regions, the practical forms of agricultural sustainable intensification are heterogeneous in different regions and agricultural systems [101]. For example, in some arid areas, rather than inputs such as irrigation, fertilizer or improved seeds, the most appropriate intensification form might be inputs related to animal health and social organizations, forming a completely different situation from other areas [60]. However, in some arid regions of North Africa and West Asia, crop yields can be significantly increased through the implementation of supplementary irrigation and good management practices, thus contributing to the sustainable intensification of crop production [1]. Being widely promoted as a model to achieve agricultural sustainable intensification in mountainous areas, agroforestry complex management is regarded as a solution to the emerging problems of reduced fallow time and land degradation [108]. In the plateau regions, as a key component of agro-ecosystems, exploring ways to protect and restore ecosystem services is the key to realize agricultural sustainable intensification [88,89]. The research on rice production in the North China Plain of China shows that precise management techniques of nitrogen fertilizer increase rice yield by $2-3$ times and reduce production's negative impact on the environment at the same time, thus providing a reference for agricultural sustainable intensification [1]. It is concluded that the implementation mode of agricultural sustainable intensification in regions of the same type may be different, and the mode in different regions is heterogeneous, reflecting the diversity in practice. Therefore, in the future, we should focus on the natural environment and socio-economic conditions in different regions. Combining the concept of agricultural sustainable intensification, select appropriate scales and typical regions, further explore the processes, trends practices and the possibility of model promotion in areas with similar socio-economic and natural environmental characteristics.

\subsection{Study on the Influencing Mechanism of Agricultural Sustainable Intensification}

It is urgent to analyze the influencing factors of agricultural sustainable intensification under the background of declining crop yield and agricultural productivity and tightened resource constraints. Although agricultural sustainable intensification can be achieved through the widely recognized and promoted technologies such as no-tillage, conservation tillage, irrigation and water harvesting, improved varieties, soil and water conservation, etc., the effects provided, its duration time and the links promoted need to be further studied. Moreover, due to the lagging effect and restraints external inputs no matter which aspect is blocked, the long-term stability of the ideal goal of sustainable intensification cannot be achieved. Therefore, we need to strengthen the research on the influencing mechanism of sustainable intensification, especially the measurement of the influencing factors including farm-scale, land tenure security, livelihood strategies, access to credit and market, infrastructure, government subsidies and system design, so as to reveal the influencing mechanism and put forward corresponding suggestions. We also need to improve measures to systematically judge the appropriate regional and comprehensive effects of the implementation of agriculture sustainable intensification. The cost of the transition to agricultural sustainable intensification, and the insufficient economic benefits generated from sustainable intensification in short term may exacerbate the multiple agricultural risks in practice. Therefore, it is urgent to construct a risk prevention mechanism and improve the according framework of agricultural sustainable intensification.

\subsection{Research on the Effect Evaluation of Agricultural Sustainable Intensification}

Sustainable intensification is an important measure to meet the current agricultural challenges. The research is based on the effects of implementing agricultural sustainable intensification, namely, whether it can reduce the pressure on the agricultural system and environment, avoid negative 
impacts on the ecological environment and promote social and economic development. The study results of the effects of agricultural sustainable intensification largely determine the formulation of policies and measures. This requires effectively combining farmers' short-term interests with society's long-term interests, especially those of the low-income developing economies. Farmers can adopt conditions, policies and institutions to realize sustainable intensification. Therefore, the focus of sustainable intensification research is to assess the ecological and socio-economic effects and welfare of smallholders adopting sustainable intensification practices, as well as regional differences.

\subsection{Study on Farmers' Incentive Mechanism of Agricultural Sustainable Intensification}

Although smallholder is the key actor to achieve food security in all countries and the main adopting body of different sustainable intensification practices, sustainable development is not necessarily the first consideration of smallholder production. Smallholder farmers' participation is determined by the profitability of sustainable intensification production. Since small farmers seek direct agricultural benefits, any path to sustainable intensification will necessarily protect or restore other ecosystem services while improving agricultural productivity. However, due to the small scale of farms, outflow of labor force, lack of farmers' land-use rights and protection for local varieties, and limited access to or lack of agricultural inputs to maintain productivity, the sustainable intensification measures taken by farmers are heterogeneous. Therefore, in the future, it is necessary to strengthen the analysis of incentive mechanisms to drive heterogeneous farmers to shift to agricultural sustainable intensification, including studies on improving social security for farmers, reducing the transaction costs of agricultural external inputs, farmers' willingness to change farming methods, providing crop insurance schemes and access to knowledge and market, figuring out the determinants of farmers' vulnerability at household level and providing compatible incentives are also the priorities in further study.

\subsection{Institutional Design Research on Agricultural Sustainable Intensification}

Lack of institutional capacity and function is a universal factor limiting agriculture in developing countries and the effective implementation of policies at the local level. The institutional design for agricultural sustainable intensification should include two basic functions: Ensuring the quality and quantity of important resources such as natural resources, nutrient resources for crop growth, knowledge and funding, and ensuring smallholder producers' access to these resources. Therefore, when the governments provide important resources including land, plant genetic resources, technology and information, farmer's financial resources, effective access to social security, in order to help farmers find stable market channels, investment, information and credit services, they should also focus on the establishment and strengthening of local government institutions and other organizations such as the service provider. Moreover, to ensure fair implementation of sustainable intensification in practice, policy design should allow families who cannot succeed through an external intensification vision to opt out to avoid negative livelihood outcomes. In addition, incorporate the construction of sustainable intensification practices adapted to climate change into institutional design, and explore the institutional design that coordinates trade-offs between agricultural development and ecosystem services. Therefore, taking household endowments and the ability to get access to external resources into account, policy design should be tailored to local conditions. At the same time, combining the relevant policy objectives of sustainable intensification, the impacts of policy implementation on the ecological environment, biodiversity and land use, human well-being and stakeholders should be comprehensively analyzed in policy design.

Author Contributions: H.X. conceptualized the research and performed the validation. Q.C. and Q.W. administered the project, developed the methodology, produced visualizations. Y.H. and Y.Z. curated the data, conducted the formal analysis and wrote and prepared the original draft manuscript. H.X. and Y.H. reviewed and edited the manuscript. H.X. acquired funding. All the authors contributed to drafting the manuscript and approved the final version of the manuscript. 
Funding: This study was supported by the National Natural Science Foundation of China (No. 41561040 \& No. 41971243); the Academic and Technical Leaders Funding Program for Major Disciplines in Jiangxi Province (No. 20172BCB22011); and the Fok Ying-Tung Fund(No. 141084).

Acknowledgments: The authors would like to thank the reviewers and the editor whose suggestions greatly improved the manuscript.

Conflicts of Interest: The authors declare no conflict of interest.

\section{Appendix A}

Table A1. Summary of the current agricultural sustainable intensification indicator system.

\begin{tabular}{|c|c|c|c|c|}
\hline Study Area & Primary Indicator & Secondary Indicators & Total Indicators ${ }^{2}$ & Source \\
\hline \multirow{5}{*}{$\begin{array}{l}\text { Sustainable Intensification } \\
\text { Indicators for Smallholder } \\
\text { Farming Systems in Africa }\end{array}$} & productivity & $\begin{array}{l}\text { yield, input efficiency, water efficiency, } \\
\text { animal health }\end{array}$ & \multirow{5}{*}{57} & \multirow{5}{*}{ [68] } \\
\hline & $\begin{array}{l}\text { economic } \\
\text { sustainability }\end{array}$ & agricultural income, crop value & & \\
\hline & $\begin{array}{l}\text { environmental } \\
\text { sustainability }\end{array}$ & $\begin{array}{l}\text { biodiversity, carbon sequestration, } \\
\text { erosion, nutrient dynamics, soil biological } \\
\text { activity, soil quality }\end{array}$ & & \\
\hline & social sustainability & information acquisition & & \\
\hline & human well-being & food and nutrition security, risk & & \\
\hline \multirow{5}{*}{$\begin{array}{l}\text { Ecological Intensification } \\
\text { Indicators for Coconut } \\
\text { Production in Brazilian } \\
\text { Farms }\end{array}$} & landscape ecology & $\begin{array}{l}\text { natural habitat status, production area } \\
\text { management and livestock/restricted } \\
\text { activities, environmental quality, } \\
\text { landscape and production diversity, risks }\end{array}$ & \multirow{5}{*}{62} & \multirow{5}{*}{ [69] } \\
\hline & $\begin{array}{l}\text { environmental } \\
\text { quality }\end{array}$ & $\begin{array}{l}\text { atmospheric emissions, water quality, soil } \\
\text { quality }\end{array}$ & & \\
\hline & $\begin{array}{l}\text { social and cultural } \\
\text { values }\end{array}$ & $\begin{array}{l}\text { education, public services, consumer } \\
\text { standards, sports and leisure, } \\
\text { cultural/natural heritage, occupational } \\
\text { health, qualified employment }\end{array}$ & & \\
\hline & economic values & $\begin{array}{l}\text { net income, income source diversity, } \\
\text { income distribution, debt, land value, } \\
\text { housing quality }\end{array}$ & & \\
\hline & management & $\begin{array}{l}\text { manager profile and dedication, manager } \\
\text { qualification and professional proficiency, } \\
\text { chemical input management }\end{array}$ & & \\
\hline \multirow{7}{*}{$\begin{array}{l}\text { Sustainable Intensification } \\
\text { Indicators for UK's } \\
\text { Agricultural System }\end{array}$} & resource systems & $\begin{array}{l}\text { productivity, land area, farm size, } \\
\text { landscape features, ruins }\end{array}$ & \multirow{7}{*}{110} & \multirow{7}{*}{ [70] } \\
\hline & resource units & $\begin{array}{l}\text { soil characteristics, biodiversity, livestock, } \\
\text { events, crop diversity, water depth }\end{array}$ & & \\
\hline & governance & $\begin{array}{l}\text { agricultural subsidies, land leases, animal } \\
\text { welfare, farmers' fair negotiation ability }\end{array}$ & & \\
\hline & resource users & $\begin{array}{l}\text { farmer age, succession plan, social } \\
\text { network, housing, employment, number } \\
\text { of native speakers }\end{array}$ & & \\
\hline & interactions & $\begin{array}{l}\text { degree of mechanization, landscape } \\
\text { characteristics, agricultural technology, } \\
\text { livestock rearing, farming quantity, crop } \\
\text { characteristics, farm size }\end{array}$ & & \\
\hline & outcomes & $\begin{array}{l}\text { yield, income, greenhouse gases, } \\
\text { agricultural pollution, resource use } \\
\text { efficiency, landscape characteristics, farm } \\
\text { size, farmer welfare }\end{array}$ & & \\
\hline & environment & $\begin{array}{l}\text { credit, product prices, agricultural } \\
\text { competitiveness, frequency of extreme } \\
\text { events, consumer characteristics, amount } \\
\text { of funds }\end{array}$ & & \\
\hline
\end{tabular}


Table A2. An excerpt from the literature on agricultural sustainable intensification studies.

\begin{tabular}{|c|c|c|c|c|c|}
\hline Authors $^{3}$ & Journal & Scale & Influencing factors and Nature of Indicators ${ }^{4}$ & Number of Indicators Used & Publication Year \\
\hline Alex Smith & Global Food Security & multi-scale & $\begin{array}{l}\text { yield }(+) \text {, input efficiency }(+) \text {, water efficiency }(+) \text {, } \\
\text { animal health }(+) \text {, agricultural income }(+), \operatorname{crop} \\
\text { value }(+), \text { food and nutrition security }(+), \operatorname{risk}(-), \\
\text { biodiversity }(+) \text {, carbon sequestration }(+) \text {, erosion }(-) \text {, } \\
\text { nutrient dynamics }(+) \text {, soil biological activity }(+) \text {, soil } \\
\text { quality }(+) \text {, information access }(-) \text {, gender equity }( \pm) \text {. }\end{array}$ & $\begin{array}{l}\text { primary indicator: } \\
\text { secondary indicators: } 17 \\
\text { three-level indicator: } 57\end{array}$ & 2017 \\
\hline B. Vanlauwe & $\begin{array}{l}\text { Environmental } \\
\text { Sustainability }\end{array}$ & farmer & $\begin{array}{l}\text { soil fertility }(+) \text {, population pressure }( \pm) \text {, production } \\
\text { gap }( \pm) \text {, livelihood strategy }( \pm) \text {, market access }(+) \text {. }\end{array}$ & $\begin{array}{l}\text { no specific number of } \\
\text { indicators }\end{array}$ & 2014 \\
\hline Daniel Kyalo Willy & Land Use Policy & farm & $\begin{array}{l}\text { maize yield }(+) \text {, mechanized land preparation }(-), \\
\text { quantity of manure used }(+) \text {, farm has cashcrop }(-), \\
\text { population density }( \pm) \text {, access to information }(+) \text {, } \\
\text { farmers' behavior }( \pm) \text {, climatic conditions }(\sim) \text {, total } \\
\text { organic carbon }( \pm) \text {. }\end{array}$ & 35 & 2019 \\
\hline David L. Ortega & World Development & farmer & $\begin{array}{l}\text { legume yield }(+) \text {, distance to market }(-) \text {, labor } \\
\text { requirements }(-) \text {, maize yield }(+) \text {, soil fertility }(+) \text {, } \\
\text { population density }(+) \text {, market access }(+) \text {, imperfect } \\
\text { infrastructure }(+) \text {, farmers' preferences }( \pm) \text {. }\end{array}$ & a total of 40 choice sets & 2016 \\
\hline Eric Rahn & $\begin{array}{l}\text { Agriculture, } \\
\text { Ecosystems and } \\
\text { Environment }\end{array}$ & farmer & $\begin{array}{l}\text { gender }(\sim) \text {, age }(-) \text {, education }(+) \text {, wealth }(+) \text {, coffee } \\
\text { importance }(+) \text {, family size and age }( \pm) \text {, member of } \\
\text { cooperative }(+) \text {, extension service }(+) \text {, access to } \\
\text { credit }(+) \text {, intercropping }( \pm) \text {, altitude }(+) \text {, slope }(-) \text {, dist. } \\
\text { Between homestead and plot }(-) \text {. }\end{array}$ & 13 & 2018 \\
\hline Fred Zaal & World Development & village & $\begin{array}{l}\text { density }(+) \text {, travel time to market( }(-) \text {, price } \\
\text { coffee/maize }(+) \text {, drought in Kitui }(+) \text {, population } \\
\text { density }(+) \text {, crop price fluctuations }(-) \text {. }\end{array}$ & 6 & 2002 \\
\hline
\end{tabular}

2 In the table, the total indicator refers to the total number of three-level indicators in the referenced literature. Among them, the reference [68] is: Measuring after intensification in smallholder agroecosystems: A review, the total numb er of three-level indicators mentioned in the literature is 57; The title of reference [69] is: Sustainability assessment of ecological intensification practices in coconut production. The total number of three-level indicators mentioned in this document is 62; The subject of reference [70] is: Towards a broad-based and holistic framework of Sustainable Intensification indicators. The total number of three-level indicators mentioned in this document is 110. 
Table A2. Cont.

\begin{tabular}{|c|c|c|c|c|c|}
\hline Authors $^{3}$ & Journal & Scale & Influencing factors and Nature of Indicators ${ }^{4}$ & Number of Indicators Used & Publication Year \\
\hline $\begin{array}{l}\text { Geraldo Stachetti } \\
\text { Rodrigues }\end{array}$ & Agricultural Systems & farm & $\begin{array}{l}\text { environmental quality }(+) \text {, landscape and production } \\
\text { diversity }(+) \text {, risks }(-) \text {, water quality }(+) \text {, soil quality }(+) \text {, } \\
\text { education }(+) \text {, public services }(+) \text {, consumer standards, } \\
\text { net income }(+) \text {, income source diversity }(-) \text {, chemical } \\
\text { input management(-). }\end{array}$ & a total of 62 indicators & 2018 \\
\hline Jonathan Vayssières & Agricultural Systems & farm & $\begin{array}{l}\text { forage productivity }(+) \text {, milk productivity (+), feed } \\
\text { conversion efficiency }(+), N \text { dynamics }(+) \text {, energy } \\
\text { consumptions }(-) \text {, the total labor requirement }(-) \text {, farm } \\
\text { type }( \pm) \text {, gross margin }(+) \text {, crop-livestock } \\
\text { integration(+), food demand growth }(+) \text {, } \\
\text { environmental stress }(+) \text {, farm self-sufficiency(-). }\end{array}$ & 12 & 2011 \\
\hline Jasmin Schiefer & $\begin{array}{l}\text { International Soil and } \\
\text { Water Conservation } \\
\text { Research }\end{array}$ & plot & $\begin{array}{l}\text { organic } \mathrm{C} \text { content }(+) \text {, claypsilt }(\sim), \mathrm{pH}( \pm) \text {, cation } \\
\text { exchange capacity }(+) \text {, population pressure }(+) \text {, food } \\
\text { demand }(+) \text {, soil organic matter }(+) \text {, slope }(-) \text {, soil } \\
\operatorname{depth}(\sim) \text {. }\end{array}$ & $\begin{array}{l}\text { six intrinsic land and soil } \\
\text { characteristics }\end{array}$ & 2015 \\
\hline José Cortez-Arriola & Agricultural Systems & farm & $\begin{array}{l}\text { biophysical environment }( \pm) \text {, socio-economics }( \pm) \text {, } \\
\text { crops }(+) \text {, crop products }(+) \text {, animals and herd } \\
\text { composition }( \pm) \text {, animal products }(+) \text {, manure types } \\
\text { and degradation }( \pm) \text {, external sources of mineral } \\
\text { nutrients }( \pm) \text {, physical assets }(+) \text {. }\end{array}$ & 30 & 2016 \\
\hline Menale Kassie & Land Use Policy & plot & $\begin{array}{l}\text { soil fertility }(+) \text {, soil depth }(\sim) \text {, plot slope }(-) \text {, distance of } \\
\text { the plot from residence }(-) \text {, tenure }(+) \text {, plot size }(\sim) \text {, } \\
\text { pests disease }(-) \text {, farm age }(-) \text {, education level }(+) \text {, } \\
\text { salary }(\sim) \text {, farm size }( \pm) \text {, walking distance to main } \\
\text { markets( }(-) \text {, agricultural extension services }(+) \text {, } \\
\text { credit-access }(+) \text {, market access }(+) \text {,individuals' social } \\
\text { networks }(+) \text {. }\end{array}$ & $\begin{array}{l}\text { six dependent variable } \\
\text { indicators }\end{array}$ & 2015 \\
\hline Mastewal Yami & $\begin{array}{c}\text { Journal of Rural } \\
\text { Studies }\end{array}$ & country & $\begin{array}{l}\text { pest management }(+) \text {, post-harvest technologies }(+) \text {, } \\
\text { agrochemicals }(-) \text {, improved varieties }(+) \text {, farm } \\
\text { technologies }(+) \text {, agriculture extension systems }(+), \\
\text { public private partnerships }(+), \text { local innovations }(+) \text {, } \\
\text { crop insurance systems }(+) \text {, income }(+) \text {, agriculture } \\
\text { finance }(+) \text {. }\end{array}$ & 16 & 2017 \\
\hline
\end{tabular}


Table A2. Cont.

\begin{tabular}{|c|c|c|c|c|c|}
\hline Authors $^{3}$ & Journal & Scale & Influencing factors and Nature of Indicators ${ }^{4}$ & Number of Indicators Used & Publication Year \\
\hline N. Mahon & Land Use Policy & multi-scale & $\begin{array}{l}\text { yield }(+) \text {, farm size }( \pm) \text {, area of irrigated land }(\sim) \text {, soil } \\
\text { organic }(+) \text {, farmland bird numbers }(+) \text {, diversity of } \\
\text { crops }(+) \text {, livestock mortality rates }(-) \text {, animal } \\
\text { welfare }(+) \text {, age of farmers }(-) \text {, educational level of } \\
\text { famers }(+) \text {, age of farm infrastructure }(-) \text {, farmer } \\
\text { attitudes towards technology }(\sim) \text {, crop rotations }(+) \text {, } \\
\text { quantity of fertilizers used per hectare }(-) \text {, extent of } \\
\text { farm mechanization }(+) \text {, farmer income }(+) \text {, water use } \\
\text { efficiency }(+) \text {, cost of production }(-) \text {, output prices }(-) \text {, } \\
\text { agriculture competitive }(+) \text {. }\end{array}$ & a total of 110 SI indicators & 2018 \\
\hline O. Cortner & Land Use Policy & farm & $\begin{array}{l}\text { culture }(\sim) \text {, market access }(+) \text {, product prices }(+) \text {, ranch } \\
\text { facilities }(+) \text {, credit access }(+) \text {, lack of marketing } \\
\text { options }(-) \text {, biotic factors }(\sim) \text {, abiotic factors }(\sim) \text {, policy } \\
\text { risks }(-) \text {. }\end{array}$ & four first-level indicators & 2019 \\
\hline S. Wagura Ndiritu & Food Policy & plot level & $\begin{array}{l}\text { plot size }(+) \text {, plot distance to residence(-), land } \\
\text { fertility }(+) \text {, plot slope }(-) \text {, plot depth }(\sim) \text {, farmer age }(-) \text {, } \\
\text { household size }(+) \text {, farm size }(-) \text {, extension services }(+) \text {, } \\
\text { distance to the nearest main market }(+) \text {, per capita } \\
\text { expenditure }(+) \text {, livestock ownership }( \pm) \text {, social } \\
\text { capital/network }( \pm) \text {. }\end{array}$ & $\begin{array}{l}\text { seven dependent variables } \\
\text { indicators }\end{array}$ & 2014 \\
\hline
\end{tabular}




\section{References}

1. Food and Agriculture Organization of the United Nations (FAO). The Ethics of Sustainable Agricultural Intensification; Ethics Series; Food and Agriculture Organization of the United Nations: Rome, Italy, 2004; pp. 3-5.

2. Senker, P. Foresight: The future of food and farming, final project report. Prometheus 2011, 29, 309-313. [CrossRef]

3. Suhardiman, D.; Giordano, M.; Leebouapao, L. Farmers' strategies as building block for rethinking sustainable intensification. Agric. Hum. Values 2016, 33, 563-574. [CrossRef]

4. Godfray, H.C.J. The debate over sustainable intensification. Food Secur. 2015, 7, 199-208. [CrossRef]

5. Davis, C. An Adventure in Applied Science: A History of the International Rice Research Institute by Robert F. Chandler. J. Hist. Sci. 1983, 74, 595-596.

6. Gordon, C.; Katy, W. Food War: What Do We Take to Feed the World; M. Publishing House of Electronics Industry: Beijin, China, 2014; pp. 46-48.

7. Stakman, E.; Bradfield, R.; Mangelsdorf, P. Campaigns against Hunger; Harvard University Press: Cambridge, MA, USA, 1967.

8. Hazell, P.B.R. An Assessment of the Impact of Agricultural research in South Asia Since the Green Revolution. Science Council Secretariat: Rome, Italy, 2008.

9. Tilman, D.; Cassman, K.G.; Matson, P.A. Agricultural sustainability and intensive production practices. Nature 2002, 418, 671-677. [CrossRef] [PubMed]

10. Wezel, A.; Soboksa, G.; Mcclelland, S. The blurred boundaries of ecological, sustainable, and agroecological intensification: A review. Agron. Sustain. Dev. 2015, 35, 1283-1295. [CrossRef]

11. Burney, J.A.; Davis, S.J.; Lobell, D.B. Greenhouse gas mitigation by agricultural intensification. Proc. Natl. Acad. Sci. USA 2010, 107, 12052-12057. [CrossRef] [PubMed]

12. Tilman, D.; Balzer, C.; Hill, J. Global food demand and the sustainable intensification of agriculture. Proc. Natl. Acad. Sci. USA 2011, 108, 20260-20264. [CrossRef]

13. Long, Y.Q.; Wu, W.B.; Yu, Q.Y. Review on the Research Progress of Intensive Use of Cultivated Land. Nat. Resour. 2018, 33, 337-350. (In Chinese)

14. Zuo, L.; Zhang, Z.; Carlson, K.M. Progress towards sustainable intensification in China challenged by land-use change. Nat. Sustain. 2018, 1, 304-313. [CrossRef]

15. Yu, Z.N.; Zhang, X.B.; Wu, C.F. Review on the Progress of Land Science Related Research in the Journals of Nature and Science from 2000 to 2016. China Land Sci. 2017, 31, 89-97. (In Chinese)

16. Zhu, H.Y.; Sun, M.H. Review and future work focus of land use intensification research. Acta Geogr. Sin. 2014, 69, 1346-1357. (In Chinese)

17. Zhang, X.H.; Yang, D.G.; Wang, C.Y. Relationship between Intensive Use of Cultivated Land and Environmental Pressure Based on Land Scale: A Case Study of 780 Lands in Tarim River Basin. Chin. Eco-Agric. 2012, 20, 635-642. (In Chinese) [CrossRef]

18. Song, M. Analysis and Evaluation of Environmental Cost in the Utilization of Cultivated Land Resources: A Case Study of Wuhan City, Hubei Province. Chin. Popul. Resour. Environ. 2013, 23, 76-83. (In Chinese)

19. Liu, Q.; Chen, L.G. Comprehensive Evaluation and Spatial Division of Sustainable Land Use in Changsha, Zhuzhou and Xiangtan Areas. Trans. Chin. Soc. Agric. Eng. 2013, 29, 245-253. (In Chinese)

20. Liu, F.; Zhang, H.Q. Evaluation of Sustainable Land Use in Main Producing Areas of Agricultural Products in China. J. Nat. Resour. 2012, 27, 1138-1153. (In Chinese)

21. Zhao, G.S.; Wang, Y.C.; Tang, X.W. Sustainability Evaluation of Intensive Farmland Ecosystem Based on Emergy Ecological Footprint Method. Trans. Chin. Soc. Agric. Eng. 2014, 30, 159-167. (In Chinese)

22. Xie, H.L.; He, Y.F.; Zou, J.L. Spatio-temporal difference analysis of cultivated land use intensity based on emergy in the Poyang Lake Eco-economic Zone of China. J. Geogr. Sci. 2016, 26, 1412-1430. [CrossRef]

$4(+),(-),( \pm),(\sim)$ represent the relationship between impact factors and agricultural sustainable intensification, respectively, which are positively correlated, negatively correlated, uncertain, and nonlinearly related.

3 Note: due to limited table space, the authors only extracted the first author of the article, the influencing factors and indicators only extracted the important influencing factors and indicators of the referenced literature. 
23. Cao, Z.L. Construction and Evaluation of Regional Agricultural Sustainable Development Index System-Taking Hengyang City as an Example. Econ. Geogr. 2012, 32, 113-116. (In Chinese)

24. Yin, G.X. Environmental risk early warning research on intensive agricultural land use based on material flow analysis. D China Agric. Univ. 2016, 33-34. (In Chinese)

25. Niu, S.D.; Lü, X.; Shi, Y.Y. Temporal and spatial patterns of sustainable intensification of agricultural land use in Shandong Province. Chin. J. Appl. Ecol. 2018, 29, 607-616. (In Chinese)

26. Kassie, M.; Teklewold, H.; Jaleta, M. Understanding the adoption of a portfolio of sustainable intensification practices in eastern and southern Africa. Land Use Policy 2015, 42, 400-411. [CrossRef]

27. Ndiritu, S.W.; Kassie, M.; Shiferaw, B. Are there systematic gender differences in the adoption of sustainable agricultural intensification practices? Evidence from Kenya. Food Policy 2014, 49, 117-127. [CrossRef]

28. David, L.O.; Kurt, B.W.; Robert, B.R. Sustainable Intensification and Farmer Preferences for Crop System Attributes: Evidence from Malawi's Central and Southern Regions. World Dev. 2016, 87, 139-151.

29. Vanlauwe, B.; Coyne, D.; Gockowski, J. Sustainable intensification and the African smallholder farmer. Curr. Opin. Environ. Sustain. 2014, 8, 15-22. [CrossRef]

30. Tittonell, P.; Giller, K.E. When yield gaps are poverty traps: The paradigm of ecological intensification in African smallholder agriculture. Field Crops Res. 2013, 143, 76-90. [CrossRef]

31. Falconnier, G.N.; Descheemaeker, K.; Traore, B. Agricultural intensification and policy interventions: Exploring plausible futures for smallholder farmers in Southern Mali. Land Use Policy 2018, 623-634. [CrossRef]

32. Franke, A.C.; Vand, B.G.J.; Giller, K.E. Which farmers benefit most from sustainable intensification? An ex-ante impact assessment of expanding grain legume production in Malawi. Eur. J. Agron. 2014, 58, 28-38. [CrossRef]

33. Duriaux, C.; Baudron, J.Y. Retaining forests within agricultural landscapes as a pathway to sustainable intensification: Evidence from Southern Ethiopia. Agric. Ecosyst. Environ. 2018, 263, 41-52. [CrossRef]

34. Cortner, O.; Garrett, R.D.; Valentim, J.F. Perceptions of integrated crop-livestock systems for sustainable intensifcation in the Brazilian Amazon. Land Use Policy 2019, 82, 841-853. [CrossRef]

35. Rosa, M.F.; Bonham, C.A.; Dempewolf, J. An integrated approach to monitoring ecosystem services and agriculture: Implications for sustainable agricultural intensification in Rwanda. Environ. Monit. Assess. 2017, 189, 15. [CrossRef]

36. Vorlaufer, T.; Falk, T.; Dufhues, T. Payments for ecosystem services and agricultural intensification: Evidence from a choice experiment on deforestation in Zambia. Ecol. Econ. 2017, 141, 95-105. [CrossRef]

37. Pretty, J.N. The Sustainable Intensification of Agriculture. In Natural Resources Forum; Blackwell Publishing Ltd.: Oxford, UK, 1997.

38. Petersen, B.; Snapp, S. What is sustainable intensification? Views from experts. Land Use Policy 2015, 46, 1-10. [CrossRef]

39. Baulcombe, D.; Crute, I.; Davies, B. Green N: Reaping the Benefits: Science and the Sustainable Intensification of Global Agriculture; Royal Society: London, UK, 2009.

40. Food and Agriculture Organization (FAO). Save and Grow. A Policymaker's Guide to the Sustainable Intensification of Smallholder Crop Production; FAO: Rome, Italy, 2011; 102p.

41. Griffon, M. Qu'est-ce que l'agriculture écologiquement intensive? In Collection: Matière à débattre et décider; Editions Quae: Versailles, France, 2013; p. 224.

42. Council, N.R. Toward Sustainable Agricultural Systems in the 21st Century; National Academies Press: Washington, DC, USA, 2010.

43. Beddington, J.R.; Asaduzzaman, M.; Clark, M. Achieving Food Security in the Face of Climate Change: Final Report from the Commission on Sustainable Agriculture and Climate Change; CGIAR Research Program on Climate Change, Agriculture and Food Security: Frederiksberg, Denmark, 2011.

44. Cassman, K.G. Ecological intensification of cereal production systems: Yield potential, soil quality, and precision agriculture. Proc. Natl. Acad. Sci. USA 1999, 96, 5952-5959. [CrossRef] [PubMed]

45. Centre de Coopération Internationale en Recherche Agronomique Pour le Développement (CIRAD). CIRAD Strateg Vision; CIRAD: Montpellier, France, 2008.

46. Food and Agriculture Organization (FAO). Organic Agriculture: Glossary on Organic Agriculture; FAO: Rome, Italy, 2009; pp. 1-173. 
47. Foley, J.A.; Ramankutty, N.; Brauman, K.A. Solutions for a cultivated planet. Nature 2011, 478, 337-342. [CrossRef] [PubMed]

48. Snapp, S.S.; Blackie, M.J.; Gilbert, R.A. Biodiversity can support a greener revolution in Africa. Proc. Natl. Acad. Sci. USA 2010, 107, 20840-20845. [CrossRef] [PubMed]

49. Gibon, A.; Sibbald, A.R.; Flamant, J.C. Livestock farming systems research in Europe and its potential contribution for managing towards sustainability in livestock farming. Lives. Prod. Sci. 1999, 61, 121-137. [CrossRef]

50. Ruerd, R.; Lee, D. Combining Internal and External Inputs for Sustainable Intensification; International Food Policy Research Institute (IFPRI): Washington, DC, USA, 2000; pp. 1-2.

51. Pretty, J. Agricultural Sustainability: Concepts, Principles and Evidence. Philos. Trans. Biol. Sci. 2008, 363, 447-465. [CrossRef]

52. Phalan, B.; Onial, M.; Balmford, A.; Green, R.E. Reconciling Food Production and Biodiversity Conservation: Land Sharing and Land Sparing Compared. Science 2011, 333, 1289-1291. [CrossRef]

53. Rudel, T.K.; Schneider, L.; Uriarte, M.; Turner, B.L.; DeFries, R.; Lawrence, D.; Geoghegan, J.; Hecht, S.; Ickowitz, A.; Lambin, E.F.; et al. Agricultural intensification and changes in cultivated areas, 1970-2005. Proc. Natl. Acad. Sci. USA 2009, 106, 20675-20680. [CrossRef]

54. Phalan, B.; Balmford, A.; Green, R.E.; Scharlemann, J.P. Minimising the harm to biodiversity of producing more food globally. Food Policy 2011, 36, S62-S71. [CrossRef]

55. Garnett, T.; Appleby, M.C.; Balmford, A. Sustainable Intensification in Agriculture: Premises and Policies. Science 2013, 341, 33-34. [CrossRef] [PubMed]

56. Godfray, H.C.J.; Beddington, J.R.; Crute, I.R. Food Security: The Challenge of Feeding 9 Billion People. Science 2010, 327, 812-818. [CrossRef] [PubMed]

57. Pretty, J.; Bharucha, Z.P. Sustainable intensification in agricultural systems. Ann. Bot. 2014, $114,1571$. [CrossRef] [PubMed]

58. Schiefer, J.; Lair, G.J.; Blum, W.E.H. Indicators for the definition of land quality as a basis for the sustainable intensification of agricultural production. Int. Soil Water Conserv. Res. 2015, 3, 42-49. [CrossRef]

59. Schiefer, J.; Lair, G.J.; Blum, W.E.H. Potential and limits of land and soil for sustainable intensification of European agriculture. Agric. Ecosyst. Environ. 2016, 230, 283-293. [CrossRef]

60. Scherer, L.A.; Verburg, P.H.; Schulp, C.J.E. Opportunities for sustainable intensification in European agriculture. Glob. Environ. Chang. 2018, 48, 43-55. [CrossRef]

61. Liao, C.; Brown, D.G. Assessments of synergistic outcomes from sustainable intensification of agriculture need to include smallholder livelihoods with food production and ecosystem services. Curr. Opin. Environ. Sustain. 2018, 32, 53-59. [CrossRef]

62. Gadanakis, Y.; Bennett, R.; Park, J. Evaluating the Sustainable Intensification of arable farms. J. Environ. Manag. 2015, 150, 288-298. [CrossRef]

63. Buckwell, A.; Nordang-Uhre, A.; Williams, A.; Polakova, J.; Blum, W.E.; Schiefer, J.; Haber, W. The Sustainable Intensification of European Agriculture; A Review Sponsored by the RISE Foundation; The RISE Foundation: Brussels, Belgium, 2014.

64. Firbank, L.G.; Elliott, J.; Drake, B. Evidence of sustainable intensification among British farms. Agric. Ecosyst. Environ. 2013, 173, 58-65. [CrossRef]

65. Matson, P.A.; Parton, W.J.; Power, A.G. Agricultural Intensification and Ecosystem Properties. Science 1997, 277, 504-509. [CrossRef]

66. Tittonell, P. Ecological intensification of agriculture-sustainable by nature. Curr. Opin. Environ. Sustain. 2014, 8, 53-61. [CrossRef]

67. Clay, N. Seeking justice in Green Revolutions: Synergies and trade-offs between large-scale and smallholder agricultural intensification in Rwanda. Geoforum 2018, 97, 352-362. [CrossRef]

68. Smith, A.; Snapp, S.; Chikowo, R. Measuring sustainable intensification in smallholder agro-ecosystems: A review. Glob. Food Secur. 2017, 12, 127-138. [CrossRef]

69. Stachetti, R.G.; Roberto, M.C. Sustainability assessment of ecological intensification practices in coconut production. Agric. Syst. 2018, 165, 71-84.

70. Mahon, N.; Crute, I.; Di, B.M. Towards a broad-based and holistic framework of Sustainable Intensification indicators. Land Use Policy 2018, 77, 576-597. [CrossRef] 
71. Slätmo, E.; Maye, D.; Duncan, J. The Framing of Sustainability in Sustainability Assessment Frameworks for Agriculture. Sociol. Rural. 2017, 57, 378-395. [CrossRef]

72. Snapp, S.S.; Grabowski, P.; Chikowo, R. Maize yield and profitability tradeoffs with social, human and environmental performance: Is sustainable intensification feasible? Agric. Syst. 2018, 162, 77-88. [CrossRef]

73. Rodrigues, G.S.; Rodrigues, I.A.; Cláudio, C.; Almeida, B. Integrated farm sustainability assessment for the environmental management of rural activities. Environ. Impact Assess. Rev. 2010, 30, 229-239. [CrossRef]

74. Bezlepkina, I.; Reidsma, P.; Sieber, S. Integrated assessment of sustainability of agricultural systems and land use: Methods, tools and applications. Agric. Syst. 2011, 104, 105-109. [CrossRef]

75. Sánchez-Escobar, F.; Coq-Huelva, D.; Sanz-Cañada, J. Measurement of sustainable intensification by the integrated analysis of energy and economic flows: Case study of the olive-oil agricultural system of Estepa, Spain. J. Clean. Prod. 2018. [CrossRef]

76. Yami, M.; Van, A.P. Policy support for sustainable crop intensification in Eastern Africa. J. Rural Stud. 2017, 55, 216-226. [CrossRef]

77. Kuosmanen, T.; Kortelainen, M. Measuring Eco-efficiency of Production with Data Envelopment Analysis. J. Ind. Ecol. 2005, 9, 14. [CrossRef]

78. Ruben, R.; Kruseman, G.; Kuyvenhoven, A. Strategies for sustainable intensification in East African highlands: Labor use and input efficiency. Agric. Econ. 2010, 34, 167-181. [CrossRef]

79. Franks, J.R. Sustainable intensification: A UK perspective. Food Policy 2014, 47, 71-80. [CrossRef]

80. Aurélie, W.M.; Jéhane, P.; Blancheton, J.P. LCA and emergy accounting of aquaculture systems: Towards ecological intensification. J. Environ. Manag. 2013, 121, 96-109.

81. Van, B.E.M.; Lammerts, B.E.T.; Van, Z.A.J. Understanding wicked problems and organized irresponsibility: Challenges for governing the sustainable intensification of chicken meat production. Curr. Opin. Environ. Sustain. 2014, 8, 1-14.

82. Jat, H.S.; Kumar, P.; Sutaliya, J.M.; Kumar, S.; Choudhary, M.; Singh, Y.; Jat, M.L. Conservation agriculture based sustainable intensification of basmati rice-wheat system in North-West India. Arch. Agron. Soil Sci. 2019, 65, 1370-1386. [CrossRef]

83. Kuyper, T.W.; Struik, P.C. Epilogue: Global food security, rhetoric, and the sustainable intensification debate. Curr. Opin. Environ. Sustain. 2014, 8, 71-79. [CrossRef]

84. Schut, M.; Van Asten, P.; Okafor, C. Sustainable intensification of agricultural systems in the Central African Highlands: The need for institutional innovation. Agric. Syst. 2016, 145, 165-176. [CrossRef]

85. Woelcke, J. Technological and policy options for sustainable agricultural intensification in eastern Uganda. Agric. Econ. 2010, 34, 129-139. [CrossRef]

86. Prager, K.; Posthumus, H. Socio-Economic Factors Influencing Farmers' Adoption of Soil Conservation Practices in Europe; Nova Science Publishers Inc.: Hauppauge, NY, USA, 2010.

87. Himmelstein, J.; Ares, A.; Van, H.E. Sustainable Intensification: A multifaceted, systemic approach to international development. J. Sci. Food Agric. 2016, 96, 4833-4839. [CrossRef] [PubMed]

88. Rahn, E.; Liebig, T.; Ghazoul, J. Opportunities for sustainable intensification of coffee agro-ecosystems along an altitudinal gradient on Mt. Elgon, Uganda. Agric. Ecosyst. Environ. 2018, 263, 31-40. [CrossRef]

89. Willy, K.D.; Muyanga, M.; Jayne, T. Can economic and environmental benefts associated with agricultural intensifcation be sustained at high population densities? A farm level empirical analysis. Land Use Policy 2019, 81, 100-110. [CrossRef] [PubMed]

90. Rolando, J.L.; Turin, C.; Ramírez, D.A. Key ecosystem services and ecological intensification of agriculture in the tropical high-Andean Puna as affected by land-use and climate changes. Agric. Ecosyst. Environ. 2017, 236, 221-233. [CrossRef]

91. Zaal, F.; Oostendorp, R.H. Explaining a Miracle: Intensification and the Transition Towards Sustainable Small-scale Agriculture in Dryland Machakos and Kitui Districts, Kenya. World Dev. 2002, 30, 1271-1287. [CrossRef]

92. Jonathan, V.; Vigne, M.; Véronique, A. Integrated participatory modelling of actual farms to support policy making on sustainable intensification. Agric. Syst. 2011, 104, 146-161.

93. Kassie, M.; Jaleta, M.; Shiferaw, B. Adoption of interrelated sustainable agricultural practices in smallholder systems: Evidence from rural Tanzania. Technol. Forecast. Soc. Chang. 2013, 80, 525-540. [CrossRef] 
94. David, R. Montgomery. Farming Revolution: Let the Soil Change Machine; M. Zhang Ganlin, Trans.; Shanghai Science and Technology Press: Shanghai, China, 2019. (In Chinese)

95. Barlowe, R. Land Resources Economics: The Economics of Real Estate; M. Gu Shuzhong Trans.; Beijing Agricultural University Press: Beijing, China, 1989.

96. Erenstein, O. Intensification or extensification? Factors affecting technology use in peri-urban lowlands along an agro-ecological gradient in West Africa. Agric. Syst. 2006, 90, 132-158. [CrossRef]

97. Zimmerer, K.S.; Carney, J.A.; Vanek, S.J. Sustainable smallholder intensification in global change? Pivotal spatial interactions, gendered livelihoods, and agrobiodiversity. Curr. Opin. Environ. Sustain. 2015, 14, 49-60. [CrossRef]

98. Reidsma, P.; Marie-Hélène, J. Farming systems analysis and design for sustainable intensification: New methods and assessments. Eur. J. Agron. 2017, 82, 203-205. [CrossRef]

99. Harvey, C.A.; Rakotobe, Z.L.; Rao, N.S. Extreme vulnerability of smallholder farmers to agricultural risks and climate change in Madagascar. Philos. Trans. R. Soc. Lond. 2014, 369, 20130089. [CrossRef] [PubMed]

100. Shaver, I.; Chain-Guadarrama, A.; Cleary, K.A. Coupled social and ecological outcomes of agricultural intensification in Costa Rica and the future of biodiversity conservation in tropical agricultural regions. Glob. Environ. Chang. 2015, 32, 74-86. [CrossRef]

101. Weltin, M.; Zasada, I.; Piorr, A. Conceptualising fields of action for sustainable intensification-A systematic literature review and application to regional case studies. Agric. Ecosyst. Environ. 2018, 257, 68-80. [CrossRef]

102. Suter, M.; Connolly, J.; Finn, J.A. Nitrogen yield advantage from grass-legume mixtures is robust over a wide range of legume proportions and environmental conditions. Glob. Chang. Biol. 2015, 21, 2424-2438. [CrossRef]

103. Sattari, S.Z.; Bouwman, A.F.; Martinez, R.R. Negative global phosphorus budgets challenge sustainable intensification of grasslands. Nat. Commun. 2016, 7, 10696. [CrossRef]

104. Jägermeyr, J.; Gerten, D.; Schaphoff, S. Integrated crop water management might sustainably halve the global food gap. Environ. Res. Lett. 2016, 11, 025002. [CrossRef]

105. Ellis, T.; Turnbull, J.F.; Knowles, T. Trends during development of Scottish salmon farming: An example of sustainable intensification? Aquaculture 2016, 458, 82-99. [CrossRef]

106. Blumenstein, B.; Siegmeier, T.; Selsam, F. A case of sustainable intensification: Stochastic farm budget optimization considering internal economic benefits of biogas production in organic agriculture. Agric. Syst. 2018, 159, 78-92. [CrossRef]

107. Tittonell, P.; Wijk, M.T.V.; Herrero, M. Beyond resource constraints-Exploring the biophysical feasibility of options for the intensification of smallholder crop-livestock systems in Vihiga district, Kenya. Agric. Syst. 2009, 101, 1-19. [CrossRef]

108. Nath, T.K.; Jashimuddin, M.; Kamrul, H.M. The sustainable intensification of agroforestry in shifting cultivation areas of Bangladesh. Agrofor. Syst. 2016, 90, 405-416. [CrossRef] 